Review

\title{
Frogs, Fish and Forestry: An Integrated Watershed Network Paradigm Conserves Biodiversity and Ecological Services
}

\author{
Hartwell H. Welsh, Jr. \\ USDA Forest Service, Pacific Southwest Research Station, 1700 Bayview Dr., Arcata, CA 95521, \\ USA; E-Mail: hwelsh@fs.fed.us; Tel.: +1-707-825-2956
}

Received: 4 August 2011; in revised form: 31 August 2011 / Accepted: 1 September 2011 /

Published: 15 September 2011

\begin{abstract}
Successfully addressing the multitude of stresses influencing forest catchments, their native biota, and the vital ecological services they provide humanity will require adapting an integrated view that incorporates the full range of natural and anthropogenic disturbances acting on these landscapes and their embedded fluvial networks. The concepts of dendritic networks, disturbance domains, the stream continuum, and hydrologic connectivity can facilitate this integration. Managing catchments based on these combined concepts would better maintain all the components of watersheds and the interacting processes that comprise their ecological integrity. To examine these ideas, I review riparian protection regulations in the Pacific Northwest of the United States, regulations considered by many to be among the best available, and evaluate their ability to protect headwater amphibians. I present evidence for the inadequacy of these rules to maintain robust populations of these amphibians, and discuss the implications of these shortcomings for downstream-dwelling coho salmon. Emphasizing headwaters (1st to 3rd-order channels), I discuss disturbance regimes and how differences in their fluvial and geomorphic processes determine the structuring of channels, their internal environments, and the composition of the resident biota. I examine amphibian dependence on specific channel attributes, and discuss links between their abundances, altered attribute states, and natural and anthropogenic disturbances. Using these examples, I discuss the limitations of current protections to maintain key attributes necessary to support robust populations of headwater amphibians, and via hydrologic connectivity, many downstream organisms. I propose that the goal of maintaining whole catchment biodiversity and ecological services could be improved by managing watersheds based on integrating science-based network organizing concepts and evaluating and adjusting outcomes with a suite of responsive bio-indicators.
\end{abstract}


Keywords: headwaters; headwater amphibians; coho salmon; bio-indicators; stream networks; hydrologic connectivity; ecological integrity; biodiversity; ecological services

\section{“To protect your rivers, protect your mountains." Emperor Yu of China, 1600 BC}

\section{Introduction}

Terrestrial landscapes and their embedded stream channel networks are the fractal units of the planet surface traditionally referred to as watersheds. The terrestrial and aquatic parts of watersheds have long been viewed and managed as separate and unrelated entities rather than different but interdependent aspects of a single system [1,2]. This is particularly evident with headwater channels which have long been viewed and treated as if independent of the larger aquatic network $[3,4]$. Headwaters channels comprise a majority of the embedded network in a catchment $[5,6]$ where they can represent over $80 \%$ of total stream length [7]. However, multiple ecological processes demonstrate how forest landscapes and their embedded dendritic networks function as a single ecosystem (e.g., [4,6]). Important examples include the interdependence of terrestrial and aquatic food webs [8], the input of nutrients to upstream and upland environments from marine ecosystems by migrating salmonids and their terrestrial predators [9-12], and the input of wood and other organic materials from forests into headwater streams that moves down through the network and into marine environments, modifying and controlling fundamental geomorphic and ecological processes in both realms [13-15].

There is increased recognition that forested watersheds are the natural units of ecoregions that provide vital ecological services like water and sustain native biodiversity in addition to providing timber products [16,17]. As such, they are the geographic units where efforts to meet the diverse requirements of society need to be merged with the best ecological research and understanding in order to meet multiple objectives without compromising the long-term productivity of these watersheds $[18,19]$.

A functional and sustainable view requires that watersheds be viewed as single entities comprised of complex interdependent processes; this understanding is essential if we hope to utilize their native biodiversity while at the same time maintain their critical ecological services in perpetuity [20,21]. Applying such a unifying watershed approach will require identifying and developing metrics of watershed status that can inform and guide the application of an integrated view. Karr [22] stated that “...organisms are the integrators of all that is happening in a watershed." Amphibians have many attributes that make them excellent candidates as biometrics of watershed conditions (see [23]). Among these attributes are their complex life cycles [24], which in most cases involves the use of both terrestrial and aquatic environments. As a result, they are sensitive to disturbances in both environments and in their interconnecting riparian interfaces [25-27].

The intent of this paper is to advance the case for an integrated view of watershed processes based on current ecological understanding using evidence from 27 years of research on the ecology of stream amphibians in the Pacific Northwest of the United States. I describe how amphibian (and riparian reptile) assemblages are structured, how this relates to fluvial, geomorphic, botanical, and macro- and micro-meteorological processes, and how these ecological interactions demonstrate the importance of an integrated watershed perspective. I discuss how the synergistic interaction of geomorphic and 
biological processes creates, promotes, and sustains biodiversity across riverscapes (e.g., [28-30]), and I argue that understanding and applying this knowledge is essential for restoring and maintaining the native flora and fauna and their closely related ecological and economic services [31].

\section{Watersheds and Forestry}

In the 1990s, the United States government advanced the Northwest Forest Plan (NWFP) [32], a forest management plan that raised the bar on stream network protections in the US Pacific Northwest (PNW) for federal lands. The plan established new standards based on the best available science at the time [33]. The NWFP recognized the reciprocal relationships between forest landscapes and their embedded channels by designing and recommending protective streamside buffers based on site-specific tree heights (Figure 1).

Figure 1. Generalized curves indicating percent of riparian ecological functions and processes occurring within varying distances from the edge of a stream channel into forested uplands (Adapted from [32]).

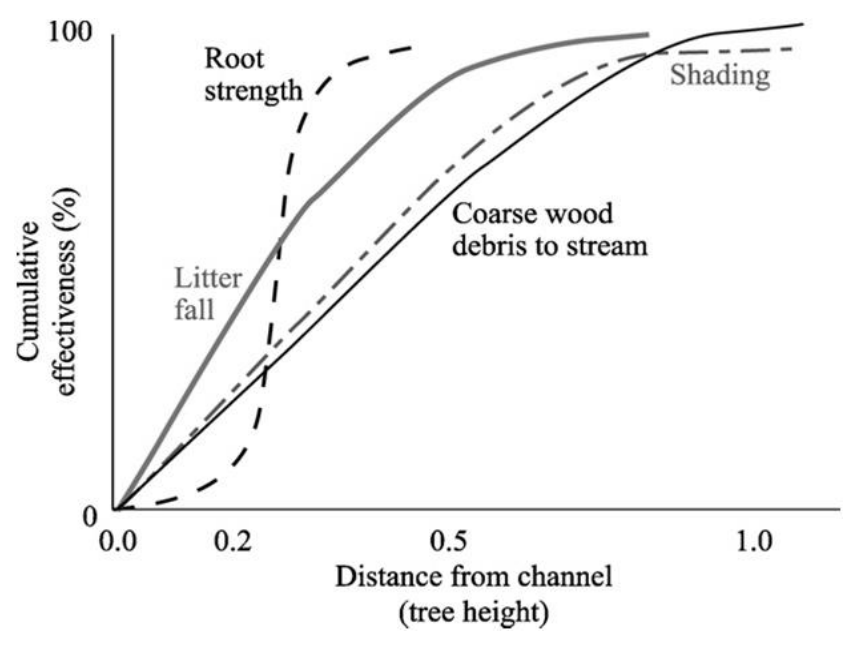

NWFP buffer widths were assigned to fish-bearing and non-fish-bearing channels, both perennial and intermittent, thereby protecting the entire network [34]. In the intervening years since NWFP implementation on federal lands, understanding the importance of protecting entire stream networks has become even more compelling as new insights regarding network processes have emerged (e.g., [35-38]).

The NWFP was intended to protect watershed processes essential for whole system integrity in the absence of site-specific knowledge that might, on a case by case basis, allow for some resource extraction that did not compromise system integrity [32]. However, NWFP protections have been largely ignored by the forestry industry and state regulatory agencies, and there has been little movement to improve stream protections under the rules of any of the three PNW states over the last 18 years (Figure 2) (see [39]). Current state forestry rules in the PNW place a heavy emphasis on 'management zones' close to stream channels as a way to protect riparian attributes (Figure 2). These management zones restrict immediate access by the heavy equipment used in forest harvesting. However, they do not protect channel stabilizing trees, overhead canopy providing shade and litter 
inputs, and other vital network functions (Figure 1), all of which are often affected when profitable riparian trees are extracted with chains or steel cables from outside these management zones. In California, the channel protections afforded headwater streams (Figure 2(b,c)) consist of just such an equipment exclusion zone. Oregon provides slightly greater protections to these channels, but Washington does not (Figure 2(b,c)). Figure 3 illustrates the effects of these inadequate headwater channel protections on the ground. This typical timber harvest occurred between 1989-1992 under current California rules. The absence of any buffers on these headwater channels allowed sediments to flow directly into the upper parts of the network when winter storms occur. A geomorphic study conducted following this harvest [40] found substantial impacts to unprotected headwater channels, with heightened run-off on harvested areas during and after storms delivering increased peak flows directly into exposed channels, resulting in head-cutting and channel incisement (Figure 4(a)). This head-cutting manifested in the down-cutting of channels, upslope migration of channel heads, and released soils into the channel network, increasing both fine sediment loads and water turbidity [40,41]. Figure 4(b) shows the extent of down-cutting on class II channels (non-fish bearing, perennial streams). Class III channels (non-fish bearing, seasonal streams) where surface flow is primarily seasonal, receive less protection. Consequently, when strong winter storms trigger the movement of sediments from the upland into these intermittent channels, the adverse effects of moving sediments are just as pronounced as in Class II channels, but more widespread because networks are comprised of greater numbers of Class III channels. This anthropogenic process eliminates critical spaces in the streambed matrix used by headwater amphibians for shelter and feeding (e.g., [23]) and negatively affects early life stages of salmonids downstream (e.g., [42,43]). The lack of adequate protection for headwaters under current rules (Figure 2) is likely to be the primary cause of the collapse of populations of stream organisms, including amphibians and salmonids, in undammed forest sub-basins throughout the PNW.

Herein I provide support for the following hypothesis: anthropogenic disturbances related to timber harvesting, combined with the lack of adequate headwater protections across the regional landscape, are negatively affecting populations of native biota throughout stream networks in the PNW. I review and combine evidence of widespread declines of headwater amphibians and the likely processes responsible, with evidence of anthropogenic disturbances to stream networks (e.g., [40,41]) resulting from the lack of headwater riparian protections [39], to argue that the delivery of sediments from hill slopes to stream network (i.e., sediment connectivity [44]), is the primary mechanism causing declines of stream organisms in headwaters and throughout channel networks. Furthermore, I would submit that these effects are cumulative because they compromise more channel habitats with each subsequent harvest rotation; and that this process is happening on a vast scale across the region as evidenced by the depauperate populations of so many native stream organisms on PNW lands devoted primarily to timber harvesting. 
Figure 2. Management systems in the US Pacific Northwest delineating riparian forest management zones. WA $=$ Washington; FFR $=$ forest and fish report; DNR $=$ Dept. Natural Resources; $\mathrm{E}=$ east; $\mathrm{W}=$ west; $\mathrm{OR}=$ Oregon; $\mathrm{CA}=$ California; $\mathrm{FPR}=$ forest practice rules; NWFP = Northwest Forest Plan. Class I, II, and III = fish-bearing, non-fish-bearing, and seasonal channels, respectively. For details see Table 4 in Olson et al. [39].

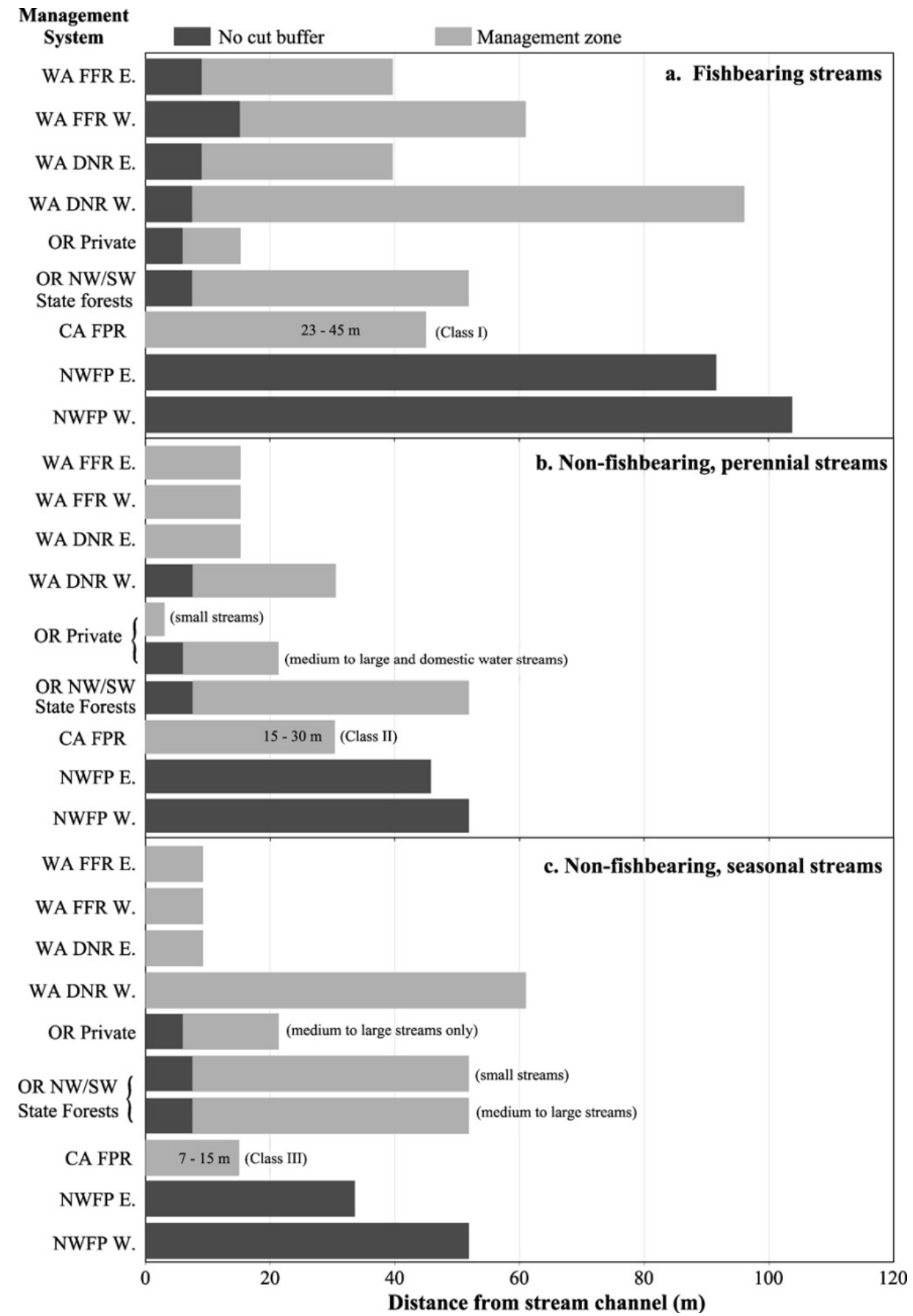


Figure 3. Typical timber harvest under current state rules. North Fork Caspar Creek, Jackson State Forest, Mendocino County, northwestern California. See Figure 4 for details of down slope effects from this exposure of the headwaters of the stream network. Photo by Tom Lisle.

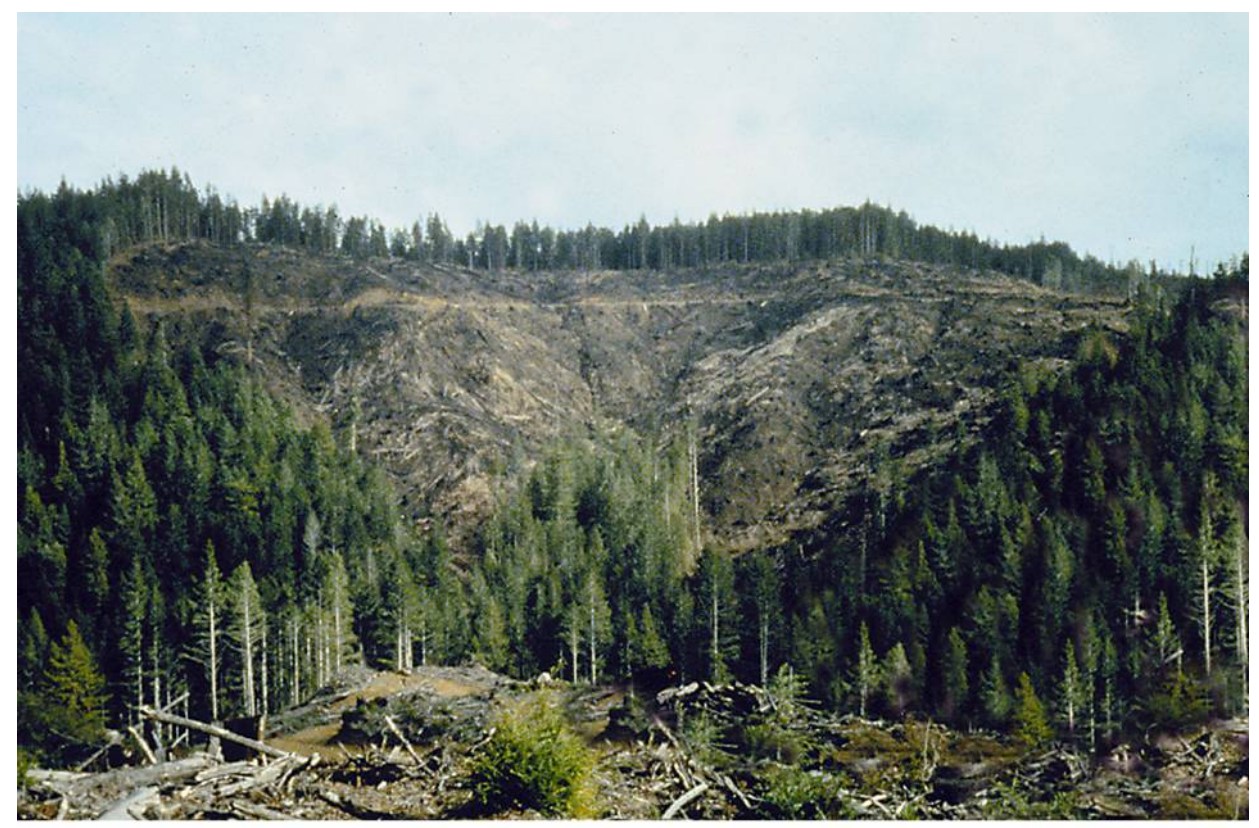

North Fork Caspar Cr., Unit G, post-burn

Figure 4. (a) Head-cutting and channel incisement immediately downstream of the harvest (Figure 3) on tributaries of North Fork Caspar Creek. Note newly exposed tree roots. Photos by S. Hilton; (b) Map of head-cutting and channel incisement (red dots) on class II tributaries of North Fork Caspar Creek post-harvest (Adapted from Dewey [41]).
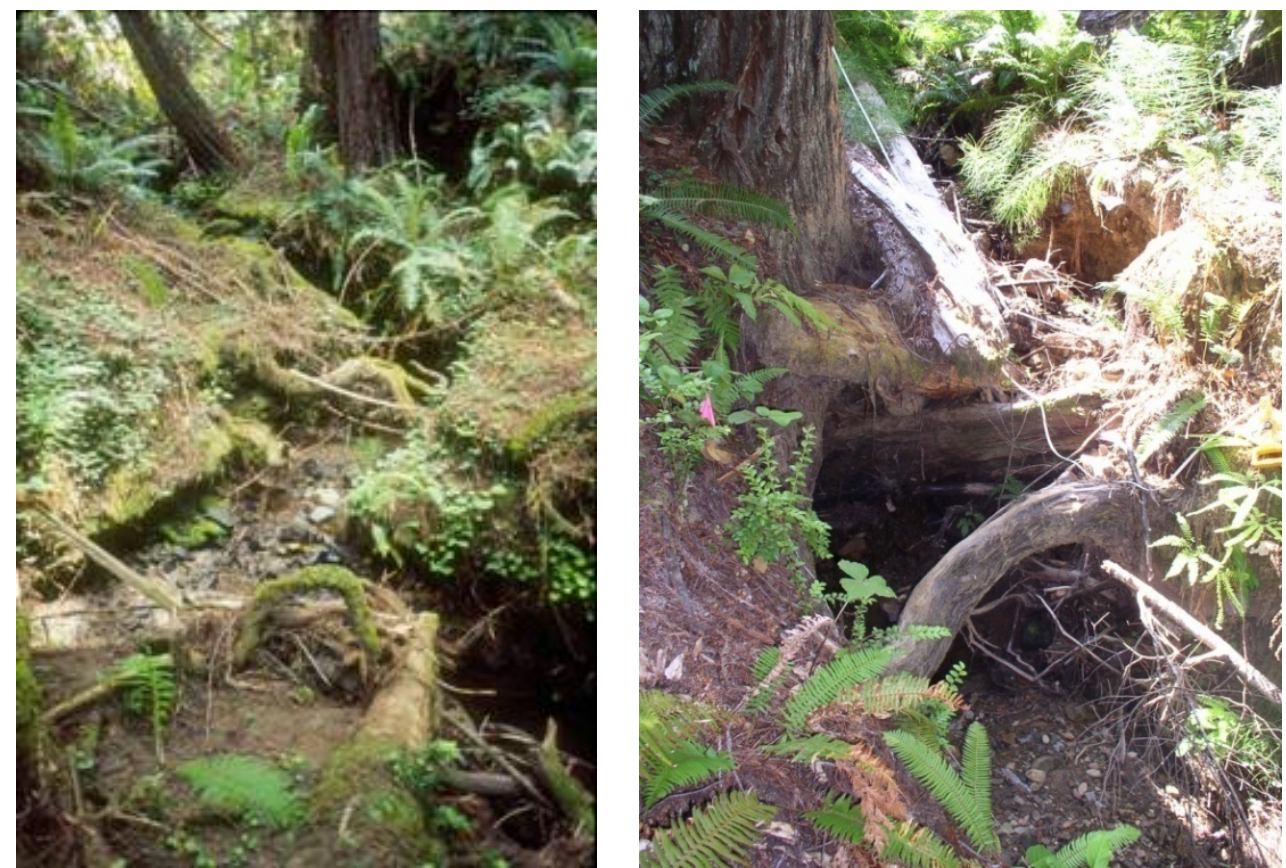

(a) 
Figure 4. Cont.

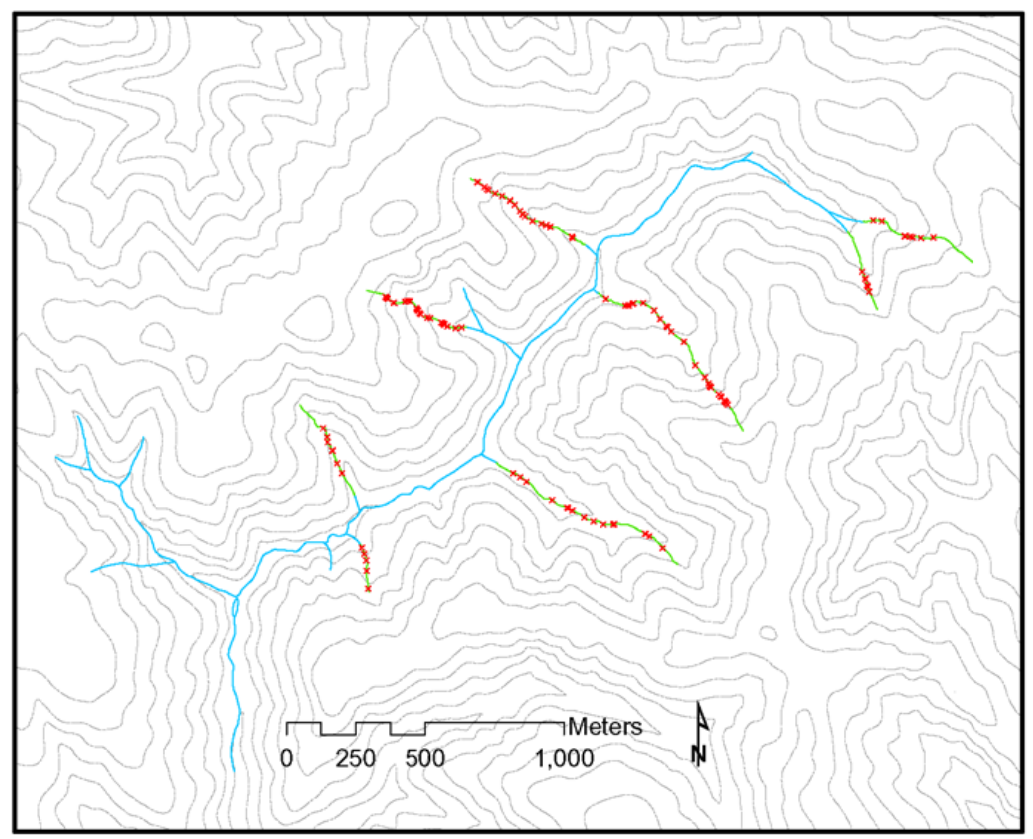

(b)

\section{The Top-down Unraveling of Stream Networks}

Evidence of the negative effects of sediment connectivity [44] on stream biota (e.g., $[23,42,43])$ is readily apparent in the relative abundances of headwater amphibians on commercial timberlands when compared with reference sites. We compared the abundances of two headwater amphibians on redwood timberland (harvested under current rules; e.g., Figure 3) with those on adjacent redwood parklands. We found significant differences of both the southern torrent salamander (Rhyacotriton variegatus) and the coastal tailed frog (Ascaphus truei) (Figure 5; [45]).

Figure 5. (a) Number of torrent salamanders (Rhyacotriton variegatus) detected per hour on commercial redwood timberlands compared with reference parklands; (b) Number of tailed frogs (Ascaphus truei) detected per hour on commercial redwood timberlands compared with reference parklands. Data from Welsh et al. [45].

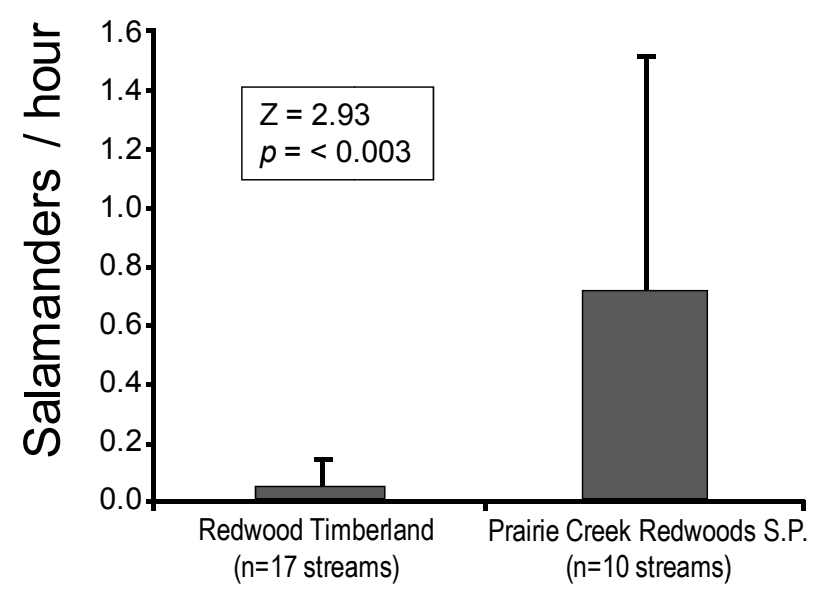

(a)

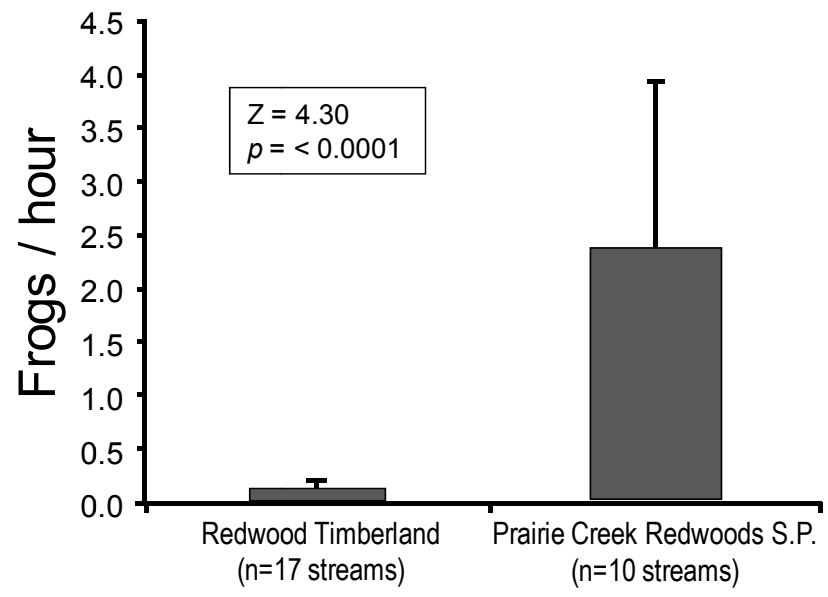

(b) 
The results of this research were consistent with earlier studies [46-48] where significant differences in the abundances of these same headwater amphibians were found between disturbed and reference sites. The redwood study [45] serves to illustrate the magnitude of the effects that can occur on the two species that appear most affected by disturbances to unprotected headwater channels. The southern torrent salamander (Figure 5(a)) is a headwater specialist [47] and member of an endemic family (Rhyacotritonidae) comprised of four species in the PNW [49]. Tailed frogs (Figure 5(b)) are ribbed frogs, the most ancient of extant frogs, a life form that predates the dinosaurs. They are also members of an endemic family (Ascaphidae), with a coastal species and another in the Rocky Mountains [50].

The earlier studies referred to above included more amphibian species, were conducted across a larger region, and included other native forest types in addition to the redwoods with sites across northwest California and southwestern Oregon [46-48]. These studies found the same reduced abundances of the torrent salamander and tailed frog where anthropogenic disturbances to headwaters channels had occurred in multiple forest types, across a broad geographic region consisting of much of the southern PNW.

In more recent research in the Mattole watershed of northwest California [51], we sampled headwater tributaries across a single entire large $\left(789 \mathrm{~km}^{2}\right)$ catchment, finding torrent salamanders and tailed frogs primarily in headwaters associated with remnant un-disturbed late-seral forest (57\% and $71 \%$ of sites, respectively; Figure 6(a)). Their occurrences correlated closely with streams where summer water temperatures remained below a critical physiological threshold for the torrent salamander and a temperature that when exceeded halted the development of tailed frog eggs; conditions that occurred primarily in streams where native forest remained intact [51]. Prior to the timber harvesting that followed World War II most of this watershed was covered with late-seral forest (Figure 6(b)). In the Mattole, the declines of native anadromous salmonids, several now nearly extinct, are often attributed to causes outside of this watershed. However, the absence of these highly sedentary headwater amphibians, except primarily in remnant late-seral forests, is not readily attributable to foreign fishing trawlers, over-fishing, sea lions, or poor ocean conditions. Furthermore, the close correspondence between these headwater amphibians and now rare coho salmon in tributaries downstream [52], strongly suggests that the declines of all of these species resulted from the same harvest-related anthropogenic disturbances as the negative effects to channel environments cascaded down through the network (e.g., $[40,41,44])$.

In more recent research in the Mattole watershed [53] we combined data from the tributary study [51] with those from the main stem river. The objective of this second study was to examine how the distributions of the herpetofauna related to network disturbance processes across the entire catchment. Here we investigated both reptiles and amphibians; while not closely related phylogenetically, these two taxa share many natural history attributes and relatively sedentary natures that make both groups highly informative when attempting to understand faunal distribution patterns and their relationships to landscape processes. The Mattole is a particularly good place to study these relationships because the river is undammed and parts of the watershed remain relatively intact and undisturbed by humans, providing the essential reference conditions $[54,55]$. 
Figure 6. (a) Detections of tailed frogs (closed circles) and torrent salamanders (closed squares) in tributaries of the Mattole River watershed. Green shading indicates remaining unharvested late-seral forests. Open symbols indicate sampling without detections. Data from Welsh et al. [51]; (b) Map of late-seral forests (green shading) in the Mattole watershed on northwest California in 1947. Modified from Mattole Restoration Council maps published in 1988 and 1997.

a.

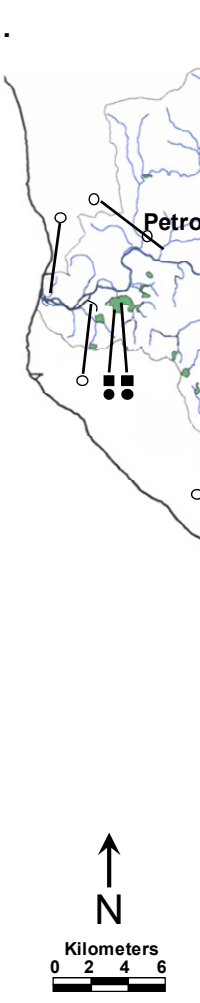

b.

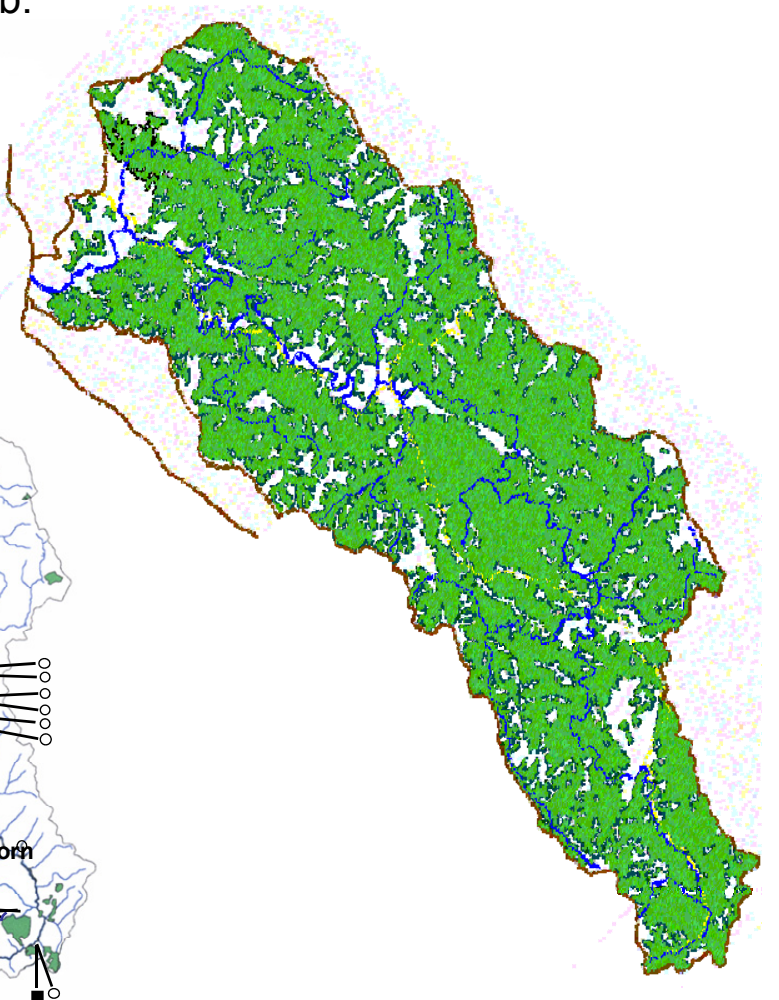

As context for understanding the results of this study one needs some knowledge of the disturbance regimes operating in the Mattole. Montgomery [56] developed a schematic model of a typical mountain catchment in the PNW, indicating how watersheds are influenced by disturbances, with the various types associated with specific regions within catchments (Figure 7; see [57]). These zones are referred to as "process domains" [56,57]. In NW California, watershed disturbances are influenced by two over-riding natural forces: (1) plate tectonics which results in steep and unstable terrain from highly active faults acting on a young and easily fragmented Franciscan geology; and (2) an annual climatic cycle with hot, dry summers and cool, wet winters with periodic intense storms. These two forces drove the pre-European natural disturbance regime, but a complete picture of the contemporary disturbance regime includes timber harvest. For example, there were more than 50 timber mills operating in southern Humboldt County in or near the Mattole watershed in the 1950s. Impacts to northern California watersheds during this same period included two major floods in 1955 and 1964. A mass wasting assessment of the north fork of the Mattole based on an analysis of aerial photos documented the extent of these combined disturbance processes in the watershed [58]. This study found only four inner gorge failures on 1948 photos; however, photos taken after the combined impacts of first-enter logging of old-growth (prior to current rules) and the two massive storm events, documented 3441 landslides [58]. The study states: “Aggressive first-entry logging using ground-based 
yarding left many of these steep streamside slopes in a vulnerable condition that resulted in extreme rates of mass-wasting when the large storms of 1955 and 1964 occurred." This study determined that debris slides from failed inner gorges delivered $96 \%$ of their total sediments to watercourses; with 2700 of these landslides delivering sediments directly into stream channels at a combined average rate of 7300 tons $/ \mathrm{mi}^{2} / \mathrm{yr}\left(2,556,942 \mathrm{~kg} / \mathrm{km}^{2} / \mathrm{yr}\right)$ [58]. The combined disturbances of aggressive logging and large storm events caused mass wasting across the watershed; the fishes and other aquatic biota have yet to recover $[59,60]$. The scale at which disturbances occur within basins is relevant to both the immediate and long-term effects on native fauna [61]. The events in the Mattole were widespread and devastating, with long-term consequences for the entire channel network and much of its aquatic biota $[59,60]$.

Montgomery's [56] concept of disturbance process domains (Figure 7) followed an earlier study on the structuring of channels in mountain basins [62]. He also developed a quantitative procedure that can determine channel types and their related process domains based on measurements of the structure and composition of the channels [63]. Channel types in each process domain are distinguishable based on parameters that derive from the interactions of the fluvial and geomorphic processes specific to the different domains (Figure 8) [63]. This model describes three basic channel types-headwater, transfer, and depositional channels - each with one or more sub-types (not shown in Figure 8). So what do the different channel types indicate about watershed process domains, and more specifically what is the relationship between channel type, these process domains, and the stream and riparian biota? By identifying a specific channel type one can infer the disturbance processes active in that particular part of the landscape; this knowledge can identify area-specific vulnerabilities and inform resource extraction activities in that area to minimize adverse impacts. Also by employing the channel types as a matrix by which to view the distributions of native biota, one can predict its potential composition. By understanding the relationships between the biota and disturbance processes active in specific areas of the landscape one can foresee potential vulnerabilities to the biota and the hydrogeomorphic processes that sustain it. The geomorphic studies of headwater channels described above [40,41] indicated mass wasting at a local scale, however, the cumulative effects of this process are measurable at a greater (landscape) scale (e.g., [58]), as it affects headwater biota regionally (e.g., Figure 5; [45]).

Our findings in the Mattole [53] serve to illustrate some of these relationships. We used ordination analysis to determine channel types in the Mattole and discerned four distinct types (Figure 9). The types above axis 1 (Figure 9) correspond to headwater and transfer channels typically dominated by debris flows driven by winter storm events; those below axis 1 are primarily depositional reaches most influenced by periodic flooding and channel migration (see Figures 7 and 8). This analysis illustrates the key features of each type, identifying the attributes that link directly to the disturbance processes acting to create and modify these different parts of the stream network. Replacing the environmental attribute vectors in Figure 9 with animal distribution vectors relative to the channel types reveals the distributions of the different species within the network; two very strong patterns are evident (Figure 10). Species above axis I are associated primarily with headwater and transfer channels (Figure 10: types I and II) (e.g., torrent salamander, tailed frog, giant salamander). Species below axis I are associated primarily with alluvial channels (Figure 10: types III and IV). Within these two general patterns individual species vary in their relationships to channel types, indicating differences at finer scales within the available types. These unique distributions are not unexpected and are consistent with 
niche theory ([64]) which considers co-occurring species to have evolved specific attributes, including relationships to the physical environment that allow them to co-exist without competitive exclusion.

Figure 7. Typical coarse-scale riverine process domains (dotted lines) for Pacific Northwest drainage basins. The shadings in each domain represent different channel types (headwater, transfer and depositional; see Figure 8) (Adapted from Naiman et al. [57]).

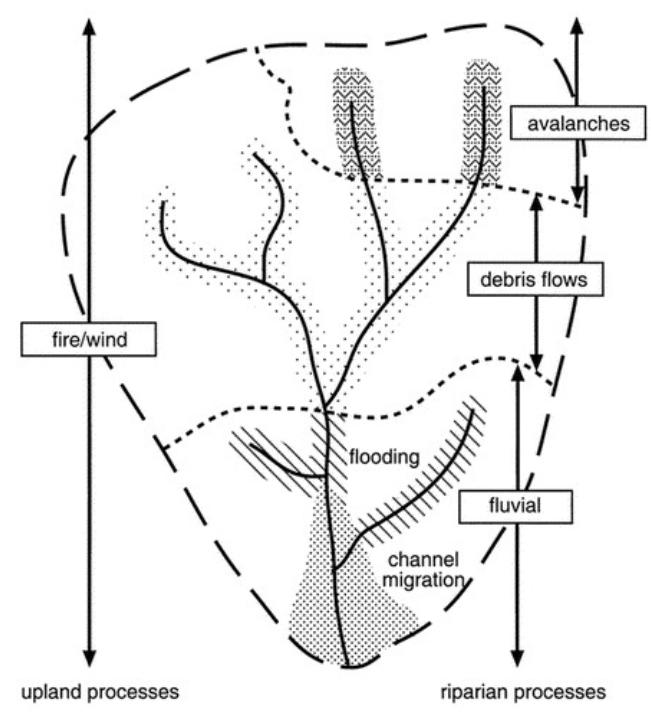

Figure 8. Changes in channel types in three process domains. Flow, channel size, and sediment characteristics change throughout the longitudinal profile. From: Stream Corridor Restoration: Principles, and Practices, 10/98, by the Federal Interagency Stream Restoration Working Group (FISRWG) (12 federal agencies of the US government).

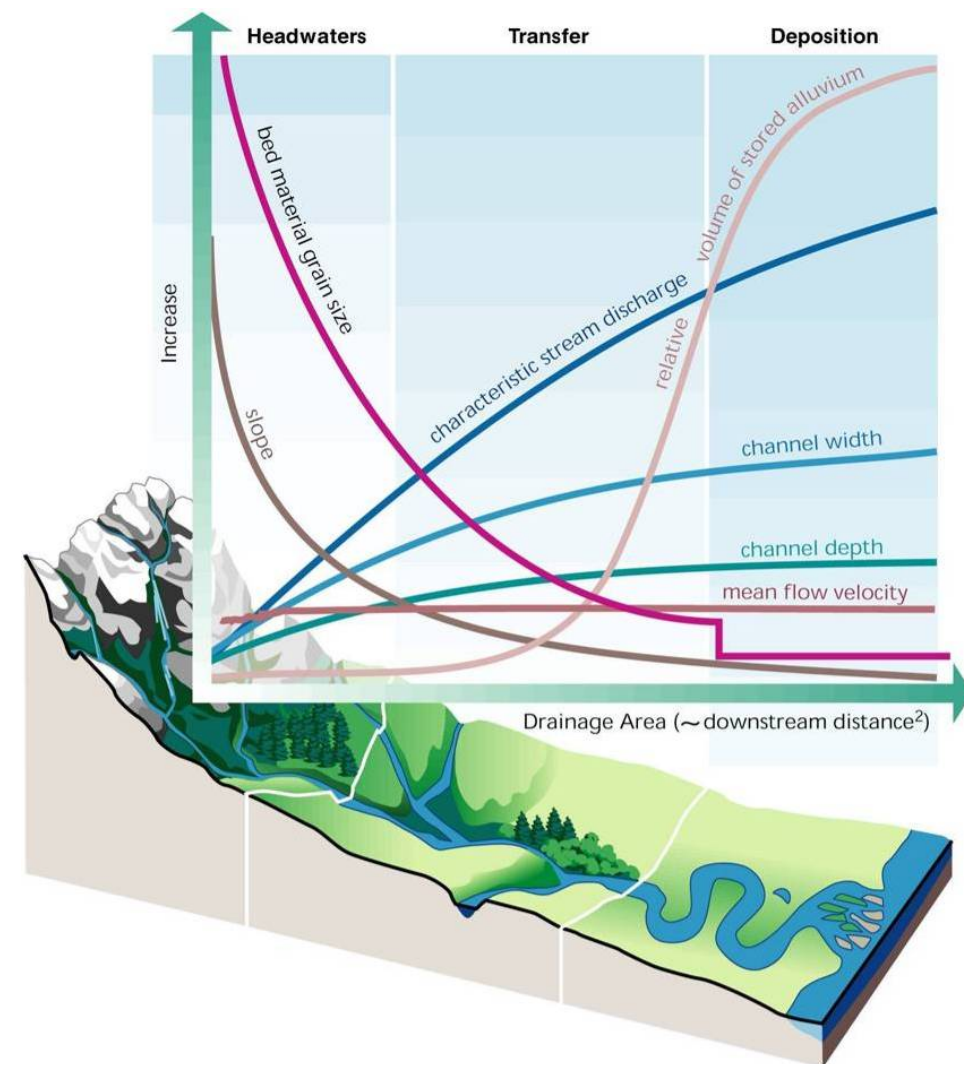


Figure 9. Non-metric multidimensional scaling (NMDS) of 83 sample reaches in the Mattole River watershed based on slope, roughness, basin area, and substrate composition. Type I = high-gradient, narrow, gorge-defined headwater channels with step pool/cascade structures; type II = moderately entrenched headwater or transfer channels with $2-4 \%$ gradients with structure controlled by moderately steep valley; type III = slightly entrenched, lower-gradient, meandering riffle/pool transfer channels with well developed flood plains; type IV = low gradient, shallow, unconfined, multiple or migrating depositional channels typical of broad alluvial valleys (from Welsh and Hodgson [53]).

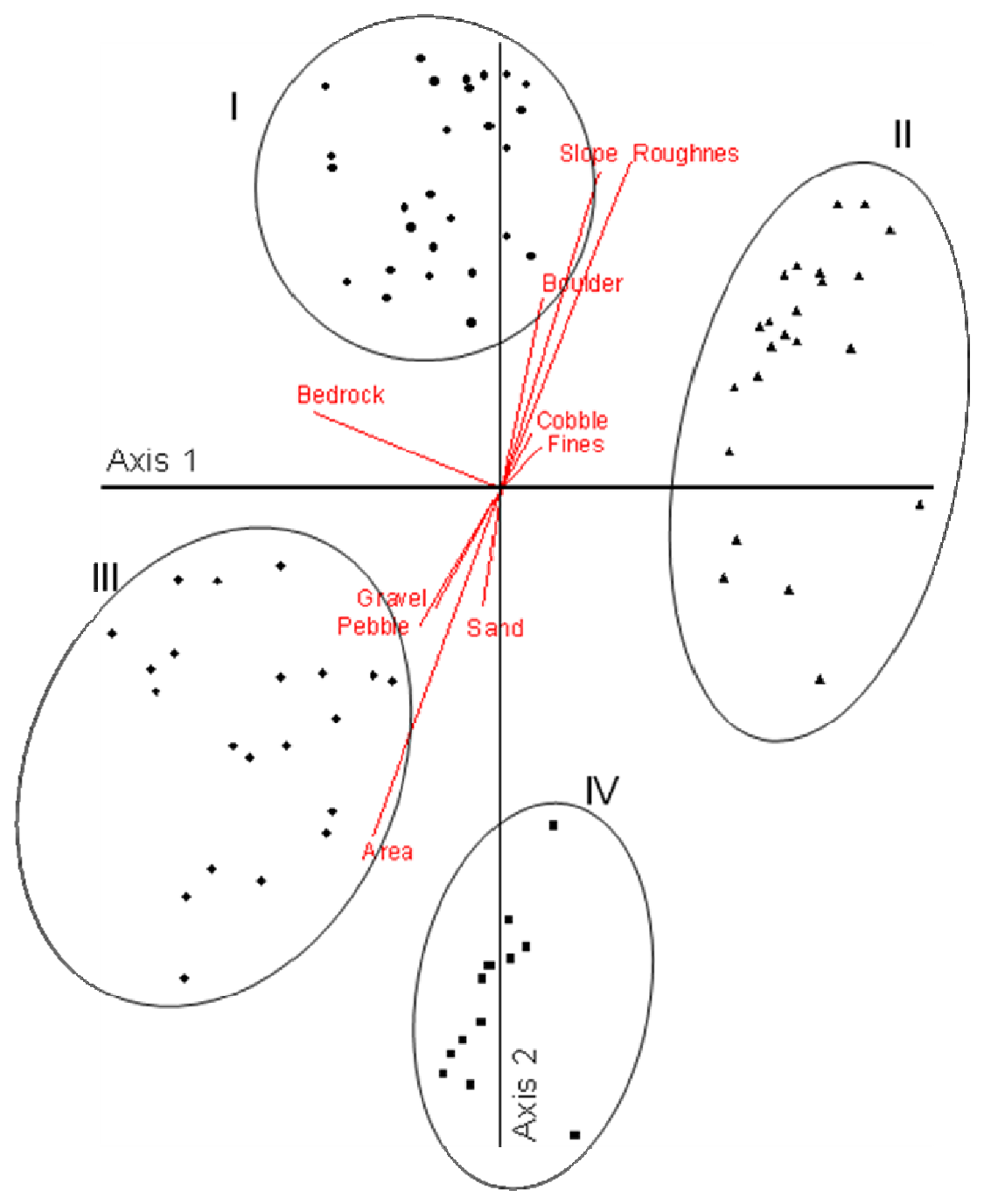


Figure 10. NMDS of 83 reaches in the Mattole watershed with the distributions of eleven amphibian and reptile species relative to the four channel types (descriptions in Figure 9). Species depicted are those distributed primarily in colluvial (I and II), alluvial (III and IV), or in all four channel types; in several cases species were found in much greater abundances in types III and IV (not shown). For details see Welsh and Hodgson [53]; Table 4, Appendix I.

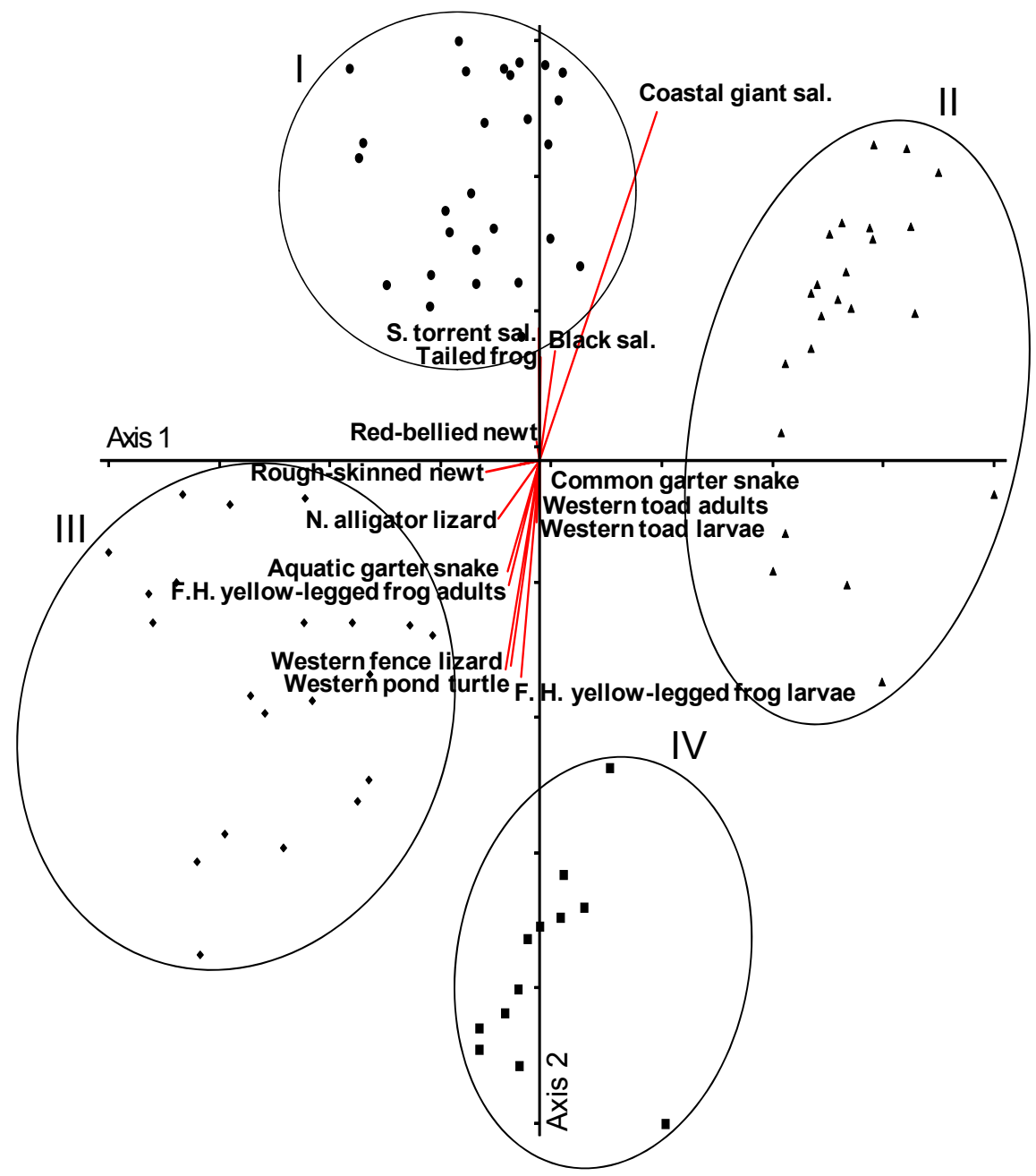

\section{Network Processes and Critical Niche Attributes}

The evidence of a changing herpetofaunal assemblage down through the stream network [53] raises the question what dictate these changes. It is reasonable to assume that these changes are related to different niches, with each species having unique adaptations to the physical environment [64]. So what might these niche attributes be, and how do they relate to changes in ecosystem processes in the various parts of the network? To better understand the specific, and possibly critical, niche attributes required by headwater amphibians, we conducted a meta-analysis that combined data from multiple studies across southern Oregon and northern California (southern PNW) to examine relationships with the three stream network attributes most often affected by anthropogenic disturbances in this region: water temperature, fine sediments, and large wood [65]. We used multi-variable generalized additive models (GAMs) to examine these attributes as they relate to three headwater amphibians (Figure 11). 
Figure 11. Shape of the estimated nonparametric function (solid line) and $95 \%$ confidence intervals (dotted lines) for the best predictive model (GAM) for (a) the southern torrent salamander; (b) the larval tailed frog; and (c) the coastal giant salamander. The functional form describes the relationship of each independent variable to the probability of salamander or larval frog presence given the inclusion of all other variables in the model. Model thresholds are indicated by those points where all three lines cross the zero axis. Vertical tick marks on the $\mathrm{x}$-axis represent variable values for each plot. Y-axis values are on the logit-scale (from Welsh and Hodgson [65]).
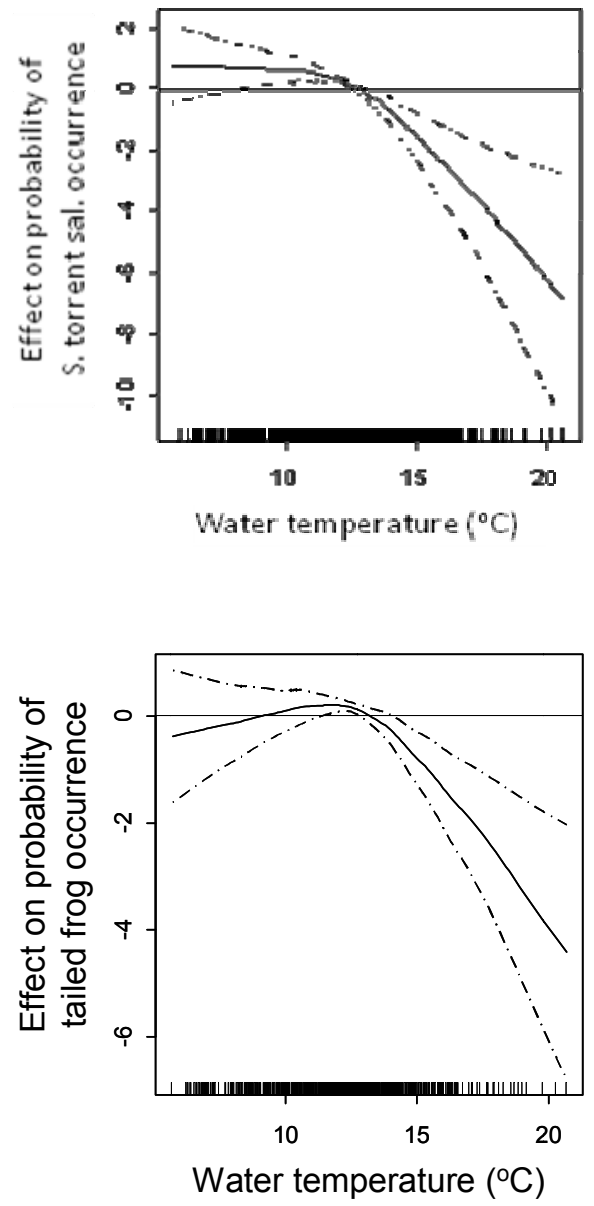

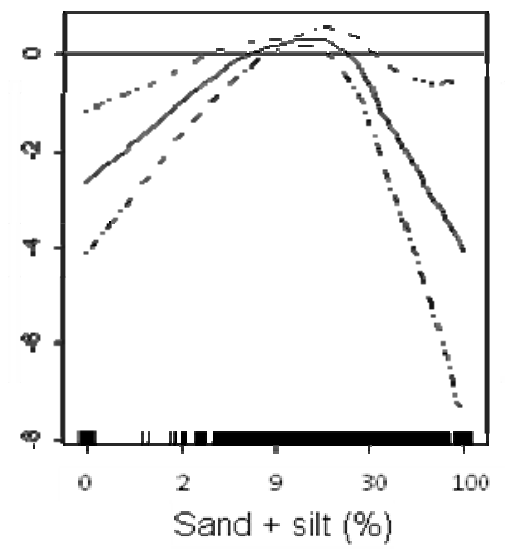

(a)

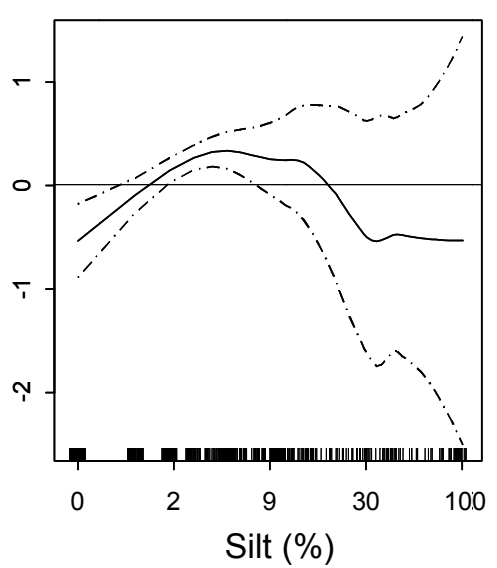

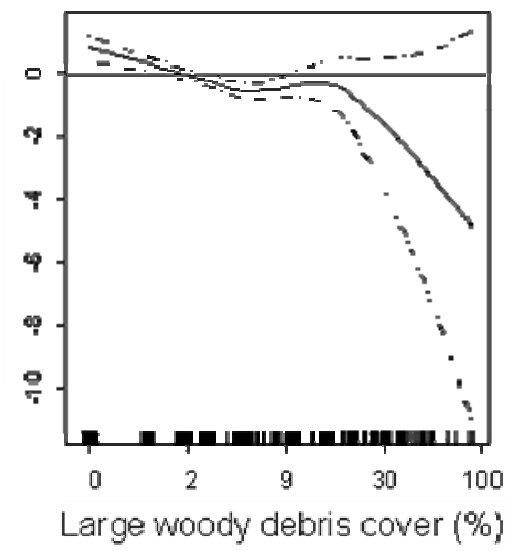

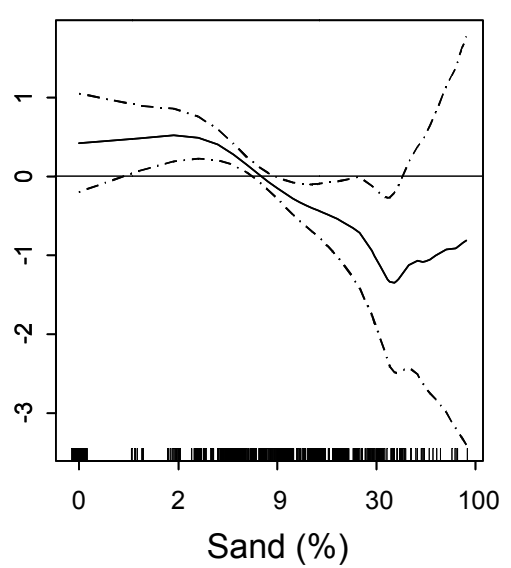

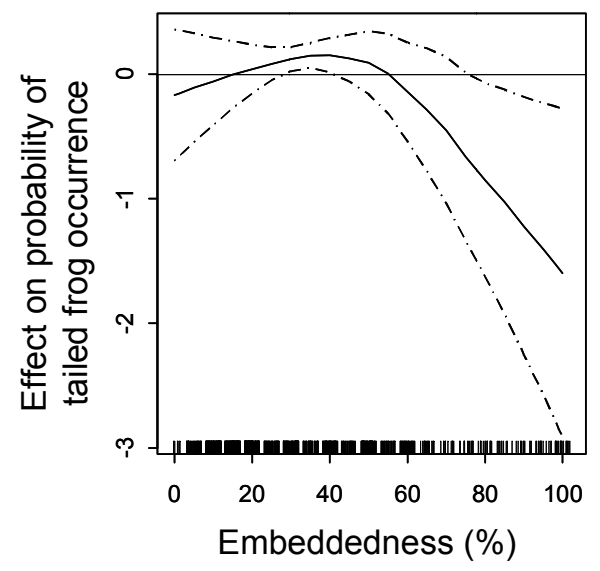

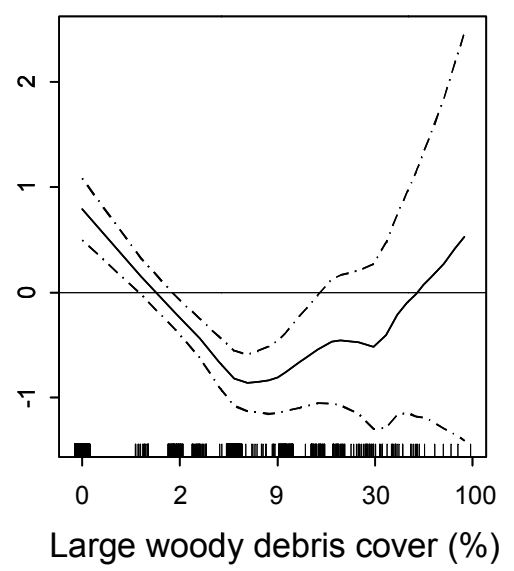

(b) 
Figure 11. Cont.
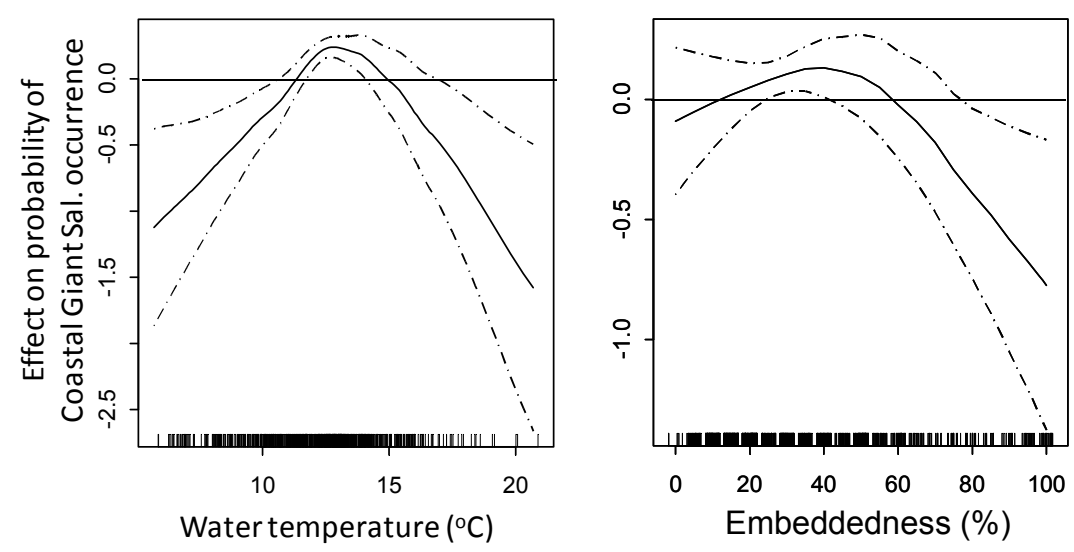

(c)

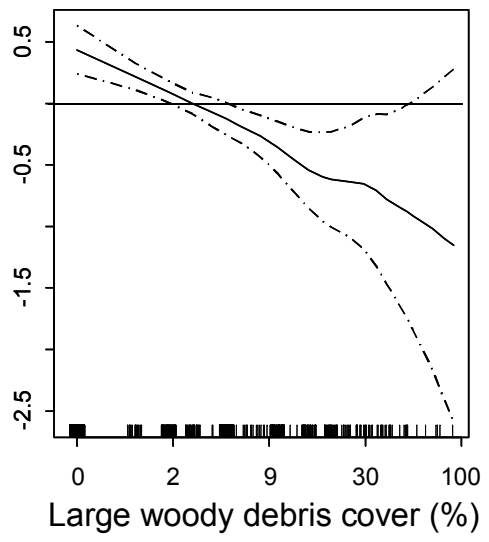

The southern torrent salamander data indicated clear thresholds for water temperature and fine sediments; the probability of finding salamanders is reduced to zero above $15.5{ }^{\circ} \mathrm{C}$, and they were found only where fine sediments were between $4 \%$ and $33 \%$ of substrate composition (Figure 11(a)). The probability of finding larval tailed frogs dramatically decreased in water temperatures $>14{ }^{\circ} \mathrm{C}$, where sand was $>9 \%$, and embeddedness was $>77 \%$ of substrate composition (Figure 11(b)). The probability of occurrence decreased above 2\% large wood cover (LW) (Figure 11(b)). For the coastal giant salamander the model indicated water temperatures where they occurred ranged from 10 to $17^{\circ} \mathrm{C}$, substrate embeddedness below $76 \%$, and LW less than 5\% (Figure 11(c)). With all three species the upper thresholds in the models were unreliable where LW was high; probably indicating the difficulty of sampling for the animals in these areas. While we could not establish clear upper thresholds for LW and these species, the data do indicate an association. The role of LW in the distribution of these amphibians is probably indirect, manifesting in how it influences the arrangement of available streambed substrates ([66]). However, the resulting fine sediment and water temperature thresholds could be useful information for maintaining robust populations of these species (see $[67,68])$.

Water temperature gradients are an important aspect of the niche of stream-dwelling species [69]. The thermal niches occupied by the amphibians in this assemblage can, like the thermal gradient of the network itself, be viewed hierarchically (Figure 12). The coldest niche is that of the headwater specialist torrent salamander [47], followed by that of the larval tailed frog, and the coastal giant salamander [48]; in many streams of the PNW this assemblage can also include juvenile coho salmon (e.g., [52]). While coho salmon have higher temperature tolerances than the three amphibians (Figure 12), and typically live further downstream, their closely aligned thermal niches (see also [70]) and hierarchical spatial relationships in the network, are consistent with what might be expected in a co-evolved cold-water-adapted fauna. 
Figure 12. Thermal niches for three headwater stream amphibians and coho salmon. Amphibian thermal niches are based on data from Welsh and Hodgson [66], coho salmon thermal niche determined from Huff et al. [70].
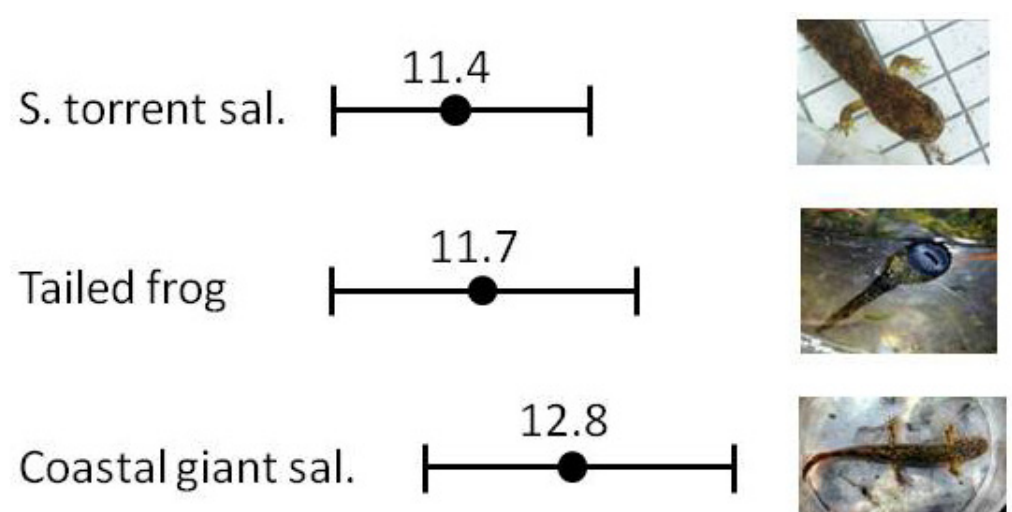

Coastalgiant sal.
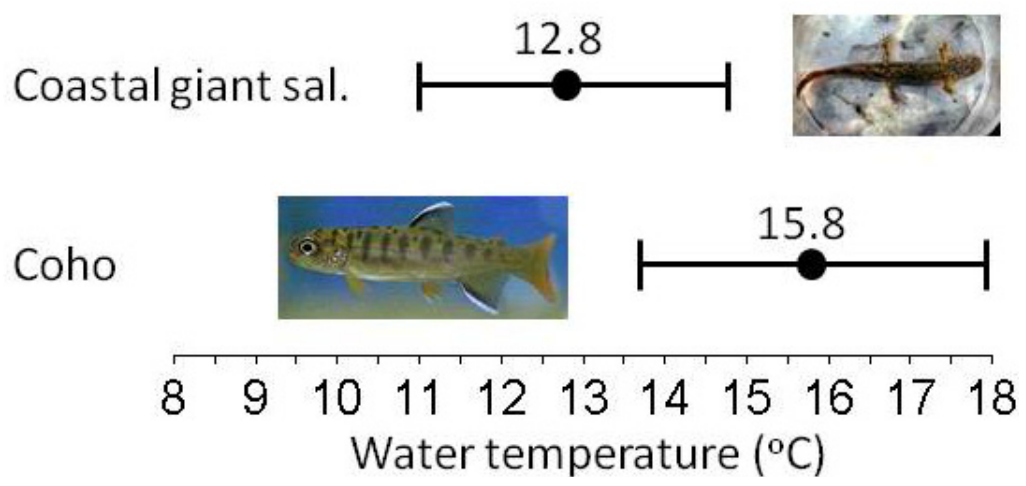

In the Mattole we sampled 26 tributary streams that were independently sampled by the non-profit Mattole Salmon Group; the Salmon Group found just nine of these streams supported over-summering juvenile coho salmon - a species not sampled in our study. Comparing these datasets, we found 8 of these 9 streams (88\%) had torrent salamanders and/or larval tailed frogs upstream of the coho [65]. Juvenile coho require cold-water summer refuges where they must put on sufficient growth in order to successfully out-migrate and return to natal streams as reproductive adults. The network juxtapositions (Figure 10) and hierarchically arranged thermal niches (Figure 12) of these unrelated species are consistent with a fundamental organizing principle of ecological assemblages based on shared influences of the physical environment [71]. This arrangement of thermal niches also suggests the possibility that the presence of these headwater amphibians could serve to indicate the ability of a stream to support over-summering coho salmon in regions where temperature is a limiting factor. These individual niche attributes are the species-specific factors that when understood and considered can facilitate the management of watersheds such that all the parts are maintained.

\section{Integrating Stream Organizing Concepts}

The hierarchical nature of these thermal niches is consistent with the model of network organization that views a stream system as a continuum [72] where abiotic and biotic processes change along predictable gradients unified by hydrologic connectivity (Figure 13). Poole [73] advanced this concept further by integrating it with the hierarchical patch dynamics perspective [74]. Hydrologic connectivity describes the continuity of fluvial networks, but more importantly, it describes the interconnectedness of the ecological processes within these systems [4,75]. As previously mentioned, this connectivity is not simply from upstream down but can also be the reverse as when salmonids deliver marine nutrients 
to upstream reaches, a process that extends into the forest when salmon carcasses are moved by bears and other predators into the terrestrial environment (e.g., [76-78]). Critical to understanding the functioning of watershed processes and maintaining their complete biota, is the fact that stream continua cross multiple process domains, as illustrated in the Mattole [53], where different disturbances exert their unique influences on channel structuring and the locally adapted biotic assemblages (Figure 10, see also [73]). Sustaining all network elements and processes requires the recognition of this fluvial interconnectedness, as well as the particular process domains (Figure 7) and their specific disturbance potentials along this continuum (e.g., $[23,42,43,45])$. Recognizing and managing networks with this integrated view (Figure 14) is vital to maintain the ecological integrity of entire catchments and the wellbeing of all of the interacting parts and ecological services (e.g., [79-81]).

Figure 13. Relationship between stream size and the progressive shift in structural and functional attributes of lotic communities (Adapted from Vannote et al. [72]).

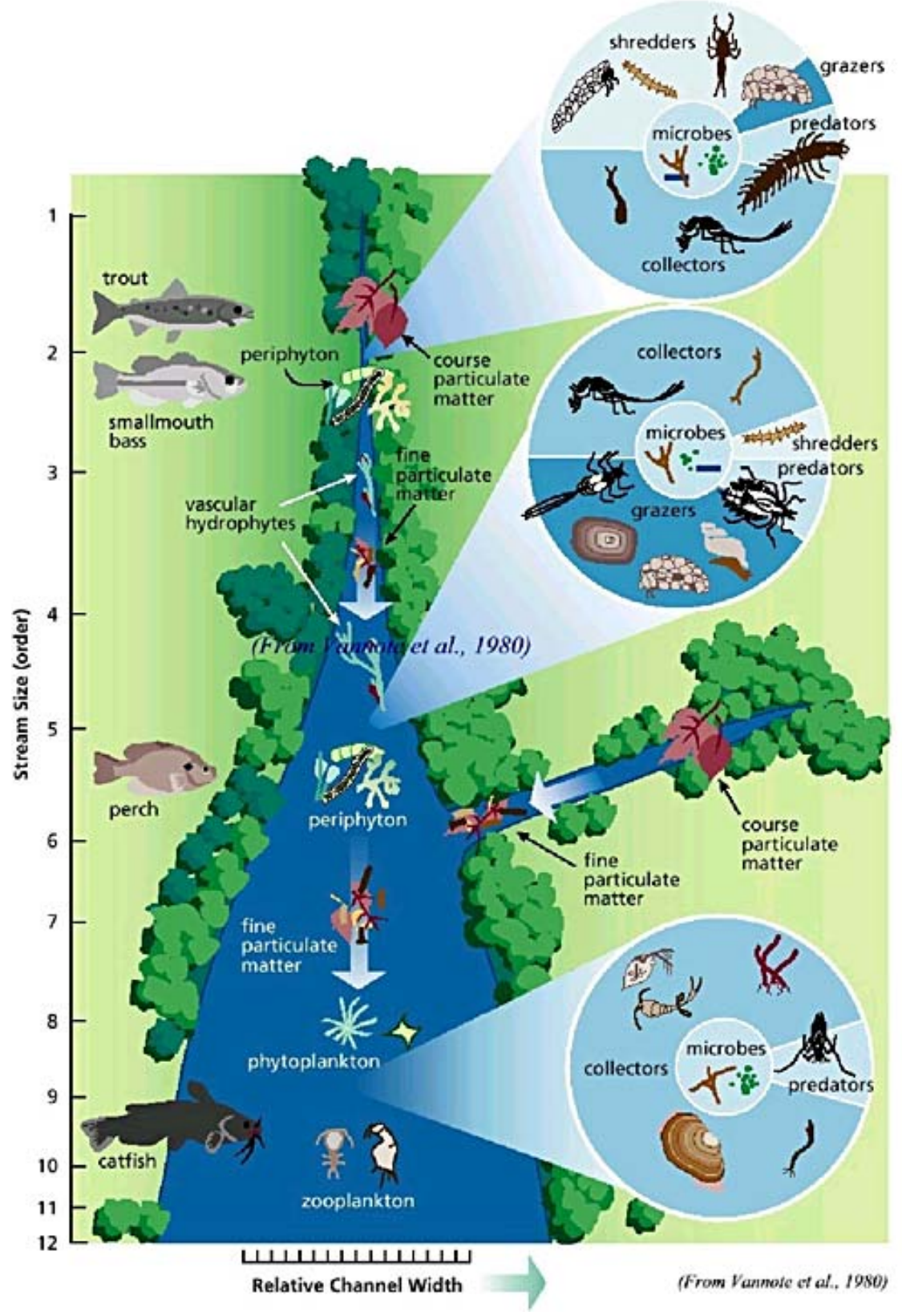


Figure 14. Each process domain (Figure 7) exerts unique hydrogeomorphic influences on the network continuum, creating and modifying specific channel types, each with its own dynamic patch mosaic of habitats. These varying patch mosaics determine the combination of flora and fauna that comprise the biodiversity within a stream network. To illustrate the concept here we have depicted part of the herpetofaunal assemblage based on [53], and identified several important ecological processes (see Figures 1 and 13 for others). A more complete list of ecological elements and processes of stream networks can be found in [45]; Table 6.1.

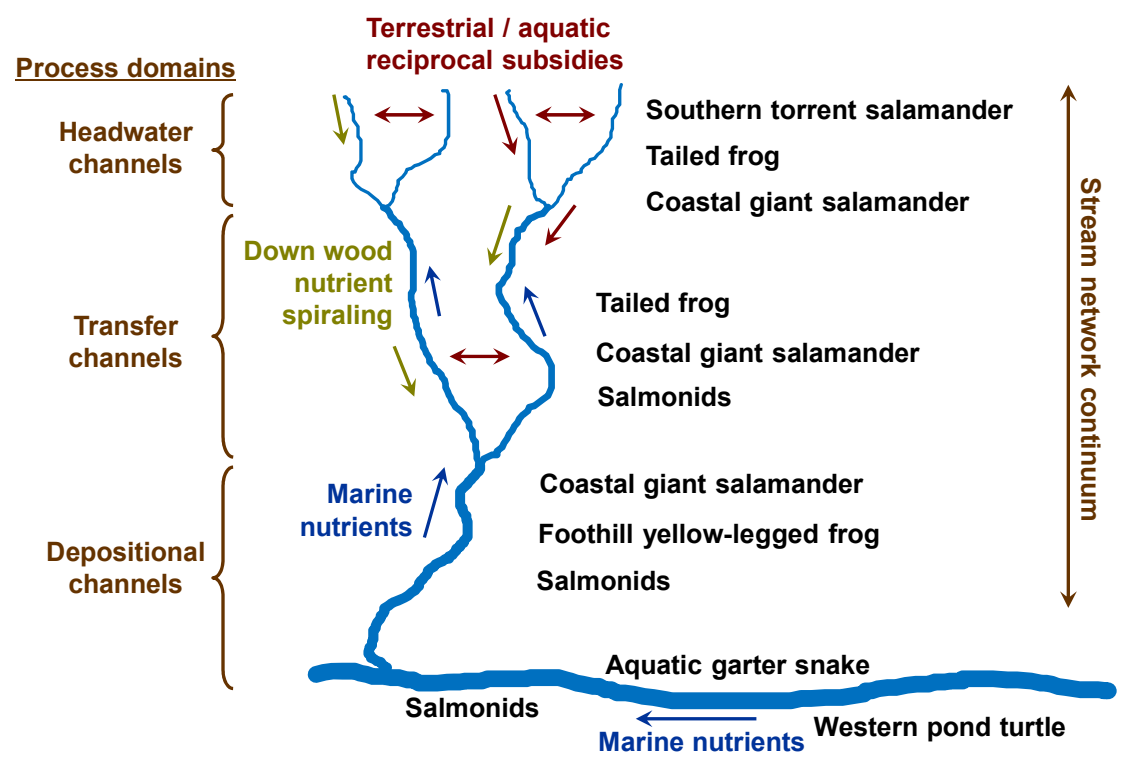

\section{Conclusions-Conserving Vital Network Conditions}

Despite efforts to develop science-based guidelines for maintaining the ecological integrity of stream networks (e.g., [34,57]), current state riparian and channel protection rules in the PNW currently fail to recognize and address how different disturbance domains influence fluvial and ecological processes, as well as how hydrologic connectivity links and reciprocally influences key network components (Figure 14). This is particularly the case with headwaters (Figure 2). Numerous studies throughout the PNW have indicated that inadequate headwater protections alter channel attributes that can then adversely affect native biota in stream networks (e.g., [82]) (see [83] for a comprehensive list of amphibian studies). For example, studies in headwater streams in early-seral, post-harvest forests have consistently found higher water temperatures and greater fine sediment loads than in comparable streams in undisturbed, primarily late-seral forest (e.g., [46-48,51]); often at temperature and sediment values exceeding those tolerated by torrent salamanders and larval tailed frogs, (e.g., $[23,51,65])$.

There has been a recent trend to present occupancy data from commercial forestry landscapes as evidence for the positive status of headwater amphibian populations in the PNW (e.g., [84,85]). There has also been an effort to discount the results of earlier studies indicating that amphibian populations had experienced negative effects on post-harvest timberlands because researchers failed to correct their data for detection probabilities [83]. There is no doubt that detection probabilities can be important 
when estimating site occupancy, particularly for wide-ranging, fast-moving, secretive, or cryptic species (e.g., forest birds, bats, carnivores). However, it is of minimal concern for sedentary and, when present, highly visible and readily detected species like stream amphibians, animals that spend their entire life cycles in and near small, readily accessible, and easily sampled stream reaches. Deriving valid and useful estimates of their numbers is just slightly more difficult than counting goldfish in a bowl. Consequently, the emphasis on the absence of detection probabilities in this research [83] lacks credibility, and ignores the obvious and more significant issue that three decades of research (i.e., the preponderance of the evidence) has documented negative effects on these species from timber harvesting in the PNW. Given repeated harvest histories, it is quite possible that the detectability of stream amphibians on some commercial timberlands may be a real issue because populations have been so decimated (e.g., Figure 5) (see [38,86]); however, recently reported detection probabilities for six headwater amphibian species on managed timber landscapes with multiple harvests (all $\geq 0.9 ;[87])$ suggests this is not a concern.

Also relevant to this issue, there are now numerous studies from managed landscapes where amphibian abundances were compared across young forest age classes, with no comparable reference stands in un-harvested late-seral forests (e.g., [88,89]). However, lacking baseline data from late-seral reference stands for comparison, one cannot assess whether populations have recovered to healthy, functional, and self-sustaining levels (see [38,86]). While headwater amphibians are often present in low numbers following harvest, their failure to recover to densities found in nearby reference streams up to six decades post-harvest [90] illustrates the flaw in accepting occupancy or abundance data only from young and/or re-grown forests as valid evidence of recovered populations. Occupancy data in particular are of little value when investigating population status; what are needed are measures of relative abundance [91] or density data from streams on commercial forestry landscapes that can be compared with similarly derived data from streams on appropriate reference stands (e.g., nearby undisturbed late-seral forest) [92] (e.g., [47,48,82]). Only by comparing data from the entire seral continuum inclusive of late-seral reference sites can one establish baseline values for these species that approximate the population levels likely to maintain ecological functionality (e.g., [93,94]). Similar data for multiple native stream taxa compared across a range of harvest treatments on PNW commercial timberlands and nearby reference stands would also be valuable. Such a multi-taxa approach is needed to establish meaningful minimal riparian protection criteria throughout catchment networks that will protect all sensitive biota and the ecological integrity of these entire systems (see [22]).

My hypothesis that the lack adequate headwater protections are having a negative effect on stream biota across the PNW needs to be evaluated at the scale at which timber harvesting is happening under lax riparian rules across thousands of watersheds from Alaska to central California, and in conjunction with the evidence of the widespread depletion of aquatic organisms and the concomitant alteration and degradation of their supporting network ecosystems. The spatial dimensions of this anthropogenic process and the evidence of its negative consequences, support the view that the failure to adequately protect headwater channels from sediment connectivity [44] and other negative alterations (e.g., altered thermal regimes) is a primary reason for the widespread negative effects on freshwater resources throughout the region. It follows logically that these systematic and widespread headwater disturbances would have additive effects with each subsequent harvest because industrial timber rotation times are not sufficient to allow the recovery of healthy network conditions and processes, as evidenced by the 
widespread cumulative effects now apparent in the PNW [95]. The widespread negative effects on most of the stream biota of the PNW, including salmonid fishes, is now evident in a large body of research (see [96] and cites therein). These effects are magnified first by this vast spatial scale, and magnified again by the direct and negative effects on the most abundant life stage of salmonids and other stream organisms - the vulnerable egg stage, where the potential for large future cohorts is compromised and vastly reduced before they are able to develop into the next generation (e.g., [51,97] and cites therein). The physical effects of these anthropogenic processes extend even into coastal, estuarine, and marine environments [98,99]. That these detrimental consequences are not better understood and remain insufficiently addressed is the result of a failure across the PNW to conduct meaningful evaluations of cumulative watershed (i.e., landscape scale) impacts [95].

While there can be regional variation in vulnerability to different types of stream network disturbances in the PNW as a result of latitude (e.g., maximum water temperatures), parent geology (e.g., fine sediments), etc.; key network attributes and processes (Figure 14) are common to catchments throughout the region (e.g., large wood, sediment sorting, thermal regimes, riparian microclimates). Consequently, the current fish-centric riparian protection rules in the PNW (Figure 2) are in need of adaptive management that recognizes and addresses all of the elements and processes that comprise the ecological integrity of entire catchments. A revised set of rules would more likely protect catchment-wide ecological integrity if it included a suite of bio-indicator species that tracked the effectiveness of improved watershed protection measures and could indicate when and where modifications were needed [22].

Strategies designed to protect steam network attributes and processes are readily available, as is evidence of their effectiveness to maintain attributes and functions while not compromising resource extraction. The Aquatic Conservation Strategy of the Northwest Forest Plan was designed to protect the integrity of entire networks [34]; however, its success has been limited because it was restricted to federally owned landscapes. The efficacy of this approach to reduce sediments into headwater channels has been confirmed by research on the highly degradable granitic parent geology of the Sierra Nevada in California [100]. In California there has been movement toward better protections with new coho salmon rules [101], but these efforts are limited in geographic scope and fall short of protecting some key headwater processes. Fortunately, some commercial timberland managers are recognizing and addressing these issues independent of state rule-making by developing their own improved guidelines, often as part of Habitat Conservation Plans being developed with relevant federal agencies. Given current efforts to re-write forest planning rules by the US Forest Service [102], along with an increased national focus on the condition of watersheds $[18,19]$, it is timely to emphasis the need to revise aquatic/riparian protections so that they are inclusive of entire catchments and their essential processes (see [96]).

If our watersheds were managed under an integrated network paradigm they could again produce large annual cohorts of anadromous species as in the past, and vacillating conditions in the marine environment would be of less consequence; as it is now, even the best ocean conditions cannot produce something out of nothing. Our watersheds, headwater amphibians, and salmon runs will not return to healthy conditions until we apply science-based protections from headwaters through downstream spawning and rearing areas, protections not trumped by economics focused on the extraction of greater basal area at the expense of native biodiversity. The notion that we can allow our watersheds to 
unravel from the top due to insufficient headwater riparian protections, in the meantime pretending that current protections are preserving salmonids and other aquatic organisms, is clearly a misguided fallacy rooted in denial. This fallacy is at the expense of many vital enterprises, beginning with those that catch, process, and supply people with wild salmon, one of the richest and most valuable protein sources available and one that supports many of the planets' societies and ecosystems. The best available science dictates a view of watersheds that provides protections based on an understanding of disturbance regimes as part of the non-equilibrium nature of ecosystems [103]. Only by understanding and respecting the synergism of fluvial, geomorphic, and ecological processes can we sustain healthy forest and stream biota. This includes the ability of those forests to grow at their maximum rates and to sequester the most atmospheric carbon (e.g., [104,105]), a subject of great relevance today in the face of global climatic shifts [106,107]. These insights, developed from research on amphibians and stream network processes in the Pacific Northwest of the United States, are relevant to biota, forests, and watersheds worldwide.

\section{Acknowledgments}

I thank Garth Hodgson and Clara Wheeler for their help in preparing this paper, and I thank all my research collaborators past and present for their hard work and insights. This paper is based on a presentation given at the Redwood Symposium, "Coast Redwood Forests in a Changing California," at the University of California, Santa Cruz, 23 June 2011. I thank Sharyn Marks and three anonymous reviewers for helpful comments on earlier drafts. The views expressed in this article are my own and not necessarily those of the agency where I work.

\section{References}

1. Wiens, J.A. Riverine landscapes: Taking landscape ecology into the water. Freshw. Biol. 2002, 47, 501-515.

2. Allan, J.D. Landscapes and riverscapes: The influence of land use on stream ecosystems. Annu. Rev. Ecol. Evol. Syst. 2004, 35, 257-284.

3. Lowe, W.H.; Likens, G.E. Moving headwater streams to the head of the class. Bioscience 2005, 55, 196-197.

4. Freeman, M.C.; Pringle, C.M.; Jackson, C.R. Hydrologic connectivity and the contribution of stream headwaters to ecological integrity at regional scales. J. Am. Water Resour. Assoc. 2007, 43, 5-14.

5. Meyer, J.L.; Wallace, J.B. Lost linkages and lotic ecology: Rediscovering small streams. In Ecology: Achievement and Challenge; Press, M.C., Huntly, N.J., Levin, S., Eds.; Blackwell Science: Oxford, UK, 2001; pp. 295-317.

6. Gomi, T.; Sidel, R.C.; Richardson, J.S. Understanding processes and downstream linkages of headwater systems. Bioscience 2002, 52, 905-916.

7. Dunne, T.; Leopold, L. Water in Environmental Planning; W.H. Freeman: New York, NY, USA, 1978.

8. Nakano, S.; Murakami, M. Reciprocal subsidies: Dynamic interdependence between terrestrial and aquatic food webs. Proc. Natl. Acad. Sci. USA 2001, 91, 166-170. 
9. Willson, M.F.; Halupka, K.C. Anadromous fish as keystone species in vertebrate communities. Conserv. Biol. 1995, 9, 489-497.

10. Helfield, J.M.; Naiman, R.J. The effects of salmon-drived nitrogen on riparian forest growth and implications for stream productivity. Ecol. Lett. 2001, 82, 2403-2409.

11. Wipfli, M.S. Trophic linkages between headwater forests and downstream fish habitats: Implications for forest and fish management. Landsc. Urban Plann. 2005, 72, 205-213.

12. Merz, J.E.; Moyle, P.B. Salmon, wildlife, and wine: Marine-derived nutrients in human-dominated ecosystems of central California. Ecol. Appl. 2006, 16, 999-1009.

13. Maser, C.; Tarrant, R.F.; Trappe, J.M.; Franklin, J.F. From the Forest to the Sea: A Story of Fallen Trees; US Department of Agriculture Forest Service: Portland, OR, USA, 1988.

14. Montgomery, D.R.; Collins, B.D.; Abbe, T.B.; Buffington, J.M. Geomorphic Effects of Wood in Rivers. In The Ecology and Management of Wood in World Rivers; Gregory, S.V., Boyer, K.L., Gurnell, A., Eds.; American Fisheries Society: Bethesda, MD, USA, 2003; AFS Symposium 37, pp. 21-47.

15. Wipfli, M.S.; Richardson, J.S.; Naiman, R.J. Ecological linkages between headwaters and downstream ecosystems: Transport or organic matter, invertebrates, and wood down headwater channels. J. Am. Water Resour. Assoc. 2007, 43, 72-85.

16. Regional Ecosystem Office, Regional Interagency Executive Committee. Ecosystem Analysis at the Watershed Scale: The Federal Guide for Watershed Analysis. Sections I and II, Version 2.2; US Department of Agriculture, Forest Service, Pacific Northwest Region: Portland, OR, USA, 1995.

17. Bohn, B.A.; Kershner, J.L. Establishing aquatic restoration priorities using a watershed approach. J. Environ. Manag. 2002, 64, 355-363.

18. National Research Council. New Strategies for America's Watersheds; National Academy Press: Washington, DC, USA, 1999.

19. Watershed Condition Framework, FS-977; US Department of Agriculture, Forest Service: Washington, DC, USA, 2011.

20. Hooper, D.U.; Chapin, F.S.; Ewel, J.J.; Hector, A.; Inchausti, P.; Lavorel, S.; Lawton, J.H.; Lodge, D.M.; Loreau, M.; Naeem, S.; Schmid, B.; Setala, H.; Symstad, A.J.; Vandermeer, J.; Wardle, D.A. Effects of biodiversity on ecosystem functioning: A consensus of current knowledge. Ecol. Monogr. 2005, 75, 3-35.

21. Dobson, A.; Lodge, D.; Alder, J.; Cumming, G.S.; Keymer, J.; Mcglade, J.; Mooney, H.; Rusak, J.A.; Sala, O.; Wolters, V.; Wall, D.; Winfree, R.; Xenopoulos, M.A. Habitat loss, trophic collapse, and the decline of ecosystem services. Ecology 2006, 87, 1915-1924.

22. Karr, J.R. Seven foundations of biological monitoring and assessment. Biol. Ambient. 2006, 20, 7-18.

23. Welsh, H.H., Jr.; Ollivier, L.M. Stream amphibians as indicators of ecosystem stress: A case study from California's redwoods. Ecol. Appl. 1998, 8, 1118-1132.

24. Wilbur, H.M. Complex life cycles and community organization in amphibians. In $A$ New Ecology: Novel Approaches to Interactive Systems; Price, P.W., Slobodchikoff, C.N., Gaud, W.S., Eds.; Wiley: New York, NY, USA, 1984; pp. 195-224. 
25. Becker, K.; Fonseca, C.R.; Haddad, C.F.B.; Batista, R.F.; Prodo, P.I. Habitat split and the global decline of amphibians. Science 2007, 318, 1775-1777.

26. Harper, E.B.; Rittenhouse, T.A.G.; Semlitsch, R.D. Demographic consequences of terrestrial habitat loss for pool-breeding amphibians: Predicting extinction risk from inadequate size of buffer zones. Conserv. Biol. 2008, 22, 1205-1215.

27. Peterman, W.E.; Semlitsch, R.D. Efficacy of riparian buffers on mitigating local population declines and effects of even-aged timber harvest on larval salamanders. For. Ecol. Manag. 2008, 257, 8-14.

28. Vernadski, V.I. La Biosphère; Librairie Félix Alcan: Paris, France, 1929. (Annotated english Translation, Springer-Verlag, Inc.: New York, NY, USA, 1998.)

29. Croizat, L. Space, Time, and Form: The Biological Synthesis; Published privately by author: Caracas, Venezuela, 1962.

30. Reinhardt, L.; Jerolmack, D.; Cardinale, B.J.; Vanacker, V.; Wright, J. Dynamic interactions of life and its landscape: Feedbacks at the interface of geomorphology and ecology. Earth Surf. Process. Landf. 2010, 35, 78-101.

31. Naeem, S.; Bunker, D.; Hector, A.; Loreau, M.; Perrings, C. Ecosystem Functioning, and Human Wellbeing: An Ecological and Economic Perspective; Oxford University Press: Oxford, UK, 2009.

32. Thomas, J.W.; Raphael, M.G. Forest Ecosystem Management: An Ecological, Economic, and Social Assessment: Report of the Forest Ecosystem Management Assessment Team; US Government Printing Office: Washington, DC, USA, 1993.

33. Thomas, J.W.; Raphael, M.G.; Anthony, R.G.; Forsman, E.D.; Gunderson, A.G.; Holthausen, R.S.; Marcot, B.G.; Reeves, G.H.; Sedell, J.R.; Solis, D.M. Viability Assessments and Management Considerations for Species Associated with Late-successional and Old-Growth Forests of the Pacific Northwest-The Report of the Scientific Analysis Team; US Department of Agriculture Forest Service, National Forest System: Washington, DC, USA, 1993.

34. Reeves, G.H.; Williams, J.E.; Burnett, K.M.; Gallo, K. The aquatic conservation strategy of the Northwest Forest Plan. Conserv. Biol. 2006, 20, 319-329.

35. Sarr, D.A.; Odion, D.C.; Hibbs, D.E.; Weikel, J.; Greewell, R.E.; Bury, R.B.; Czarnomski, N.M.; Pabst, R.J.; Shatford, J.; Moldenk, A.R. Riparian Zone Forest Management and the Protection of Biodiversity: A Problem Analysis; National Council for Air and Stream Improvement: Research Triangle Park, NC, USA, 2005.

36. Lowe, W.H.; Likens, G.E.; Power, M.E. Linking scales in stream ecology. Bioscience 2006, 56, 591-597.

37. Grant, E.H.C.; Lowe, W.H.; Fagan, W.F. Living in the branches: Population and ecological processes in dendritic networks. Ecol. Lett. 2007, 10, 165-175.

38. Humphries, P.; Winemiller, K.O. Historical impacts on river fauna, shifting baselines, and challenges for restoration. Bioscience 2009, 59, 673-684.

39. Olson, D.H.; Anderson, P.D.; Frissell, C.A.; Welsh, H.H., Jr.; Bradford, D.F. Biodiversity management approaches for stream-riparian areas: Microclimates and amphibians. For. Ecol. Manag. 2007, 246, 81-107. 
40. Reid, L.M.; Dewey, N.J.; Lisle, T.E.; Hilton, S. The incidence and role of gullies after logging in a coastal redwood forest. Geomorphology 2009, 117, 155-169.

41. Dewey, N.J. Gullies and Sediment Delivery at Caspar Creek, Mendocino County, California; MS Thesis; Humboldt State University: Arcata, CA, USA, 2007.

42. Suttle, K.B.; Power, M.E.; Levine, J.M.; Mcneely, C. How fine sediment in riverbeds impairs growth and survival of juvenile salmonids. Ecol. Appl. 2004, 14, 969-974.

43. Harvey, B.C.; White, J.L.; Nakamoto, R.J. The effect of deposited fine sediment on summer survival and growth of rainbow trout in riffles of a small stream. N. Am. J. Fish. Manag. 2009, 29, 434-440.

44. Bracken, L.; Croke, J. The concept of hydrological connectivity and its contribution to understanding runoff-dominated geomorphic systems. Hydrol. Process. 2007, 21, 1749-1763.

45. Welsh, H.H., Jr.; Roelofs, T.D.; Frissell, C.A. Aquatic ecosystems of the Redwood Region. In The Redwood Forest: History, Ecology, and Management of the Coast Redwoods; Noss, R., Ed.; Island Press: Washington, DC, USA, 2000; pp. 165-199.

46. Welsh, H.H., Jr. Relictual amphibians and old-growth forests. Conserv. Biol. 1990, 4, 309-319.

47. Welsh, H.H., Jr.; Lind, A.J. Habitat correlates of the southern torrent salamander, Rhyacotriton variegatus (Caudata: Rhyacotritonidae), in northwestern California. J. Herpetol. 1996, 30, 385-398.

48. Welsh, H.H., Jr.; Lind, A.J. Multi-scale habitat relationships of stream amphibians in the Klamath-Siskiyou Region of California and Oregon. J. Wildl. Manag. 2002, 66, 581-602.

49. Good, D.A.; Wake, D.B. Geographic Variation and Speciation in the Torrent Salamanders of the Genus Rhyacotriton (Caudata: Rhyacotritonidae); University of California Press: Berkeley, CA, USA, 1992.

50. Nielson, M.; Lohman, K.; Sullivan, J. Phylogeography of the tailed frog (Ascaphus truei): Implications for the biogeography of the Pacific Northwest. Evolution 2001, 55, 147-160.

51. Welsh, H.H., Jr.; Hodgson, G.R.; Lind, A.J. Ecogeography of the herpetofauna of a northern California watershed: Linking species patterns to landscape processes. Ecography 2005, 28, 521-536.

52. Welsh, H.H., Jr.; Hodgson, G.R.; Harvey, B.C.; Roche, M.F. Distribution of juvenile coho salmon in relation to water temperatures in tributaries of the Mattole watershed of northern California. North Am. J. Fish. Manag. 2001, 21, 464-470.

53. Welsh, H.H., Jr.; Hodgson, G.R. Spatial relationships in a dendritic network: The herpetofaunal metacommunity of the Mattole River catchment of northwest California. Ecography 2011, 34, 49-66.

54. Foster, D.; Swanson, F.; Aber, J.; Burke, I.; Brokaw, N.; Tilman, D.; Knapp, A. The importance of land-use legacies to ecology and conservation. Bioscience 2003, 53, 77-88.

55. Willis, K.J.; Birks, H.J.B. What is natural? The need for a long-term perspective in biodiversity conservation science. Science 2006, 314, 1261-1265.

56. Montgomery, D.R. Process domains and the river continuum. J. Am. Water Resour. Assoc. 1999, 35, 397-410.

57. Naiman, R.J.; Bilby, R.E.; Bisson, P.A. Riparian ecology and management in the Pacific coastal rainforest. Bioscience 2000, 50, 996-1011. 
58. SHN Consulting Engineers and Geologists. North Fork Mattole watershed mass wasting assessment (draft report). Contracted by Pacific Lumber Co, Eureka, CA, USA, 2006.

59. Mattole Restoration Council. An Inventory of Upslope Sources of Sedimentation in the Mattole River Watershed. Prepared for the California Department of Fish and Game; Mattole Restoration Council: Petrolia, CA, USA, 1989.

60. Mattole Restoration Council. Dynamics of Recovery, a Plan to Enhance the Mattole Estuary. Prepared for the California State Coastal Conservancy; Mattole Restoration Council: Petrolia, CA, USA, 1995.

61. Reeves, G.H.; Benda, L.E.; Burnett, K.M.; Bisson, P.A.; Sedell, J.R. A disturbance-based ecosystem approach to maintaining and restoring freshwater habitats of evolutionarily significant units of anadromous salmonids in the Pacific Northwest. Am. Fish. Soc. Symp. 1995, 17, 334-249.

62. Montgomery, D.R.; Abbe, T.B.; Buffington, J.M.; Peterson, N.P.; Schmidt, K.M.; Stock, J.D. Distribution of bedrock and alluvial channels in forested mountain drainage basins. Nature 1996, 381, 587-589.

63. Montgomery, D.R.; Buffington, J.M. Channel-reach morphology in mountain drainage basins. Geol. Soc. Am. Bull. 1997, 109, 596-611.

64. Chase, J.M.; Leibold, M.A. Ecological Niches, Linking Classical and Contemporary Approaches; University of Chicago Press: Chicago, IL, USA, 2003.

65. Welsh, H.H., Jr.; Hodgson, G.R. Amphibians as metrics of critical biological thresholds in forested headwater systems of the Pacific Northwest, USA. Freshw. Biol. 2008, 53, 1470-1488.

66. Abbe, T.B.; Montgomery, D.R. Large woody debris jams, channel hydraulics, and habitat formation in large rivers. Reg. River Res. Manag. 1996, 12, 201-221.

67. Huggert, A.J. The concept and utility of "ecological thresholds" in biodiversity conservation. Biol. Conserv. 2005, 124, 301-310.

68. Groffman, P.M.; Baron, J.S.; Blett, T.; Gold, A.J.; Goodman, I.; Gunderson, L.H.; Levinson, B.M.; Palmer, M.A.; Paerl, H.W.; Peterson, G.D.; et al. Ecological thresholds: The key to successful environmental management or an important concept with no practical application? Ecosystems 2006, 9, 1-13.

69. Magnuson, J.J.; Crowder, L.B.; Medvick, P.A. Temperature as an ecological resource. Am. Zool. 1979, 19, 331-343.

70. Huff, D.D.; Hubler, S.L.; Borisenko, A.N. Using field data to estimate the realized thermal niche of aquatic vertebrates. N. Am. J. Fish. Manag. 2005, 25, 346-360.

71. Andrewartha, H.G.; Birch, L.C. The Ecological Web; University of Chicago Press: Chicago, IL, USA, 1984.

72. Vannote, R.L.; Minshall, G.W.; Cummins, K.W.; Sedell, J.R.; Cushing, C.E. The river continuum concept. Can. J. Fish. Aquat. Sci. 1980, 37, 130-137.

73. Poole, G.C. Fluvial landscape ecology: Addressing uniqueness within the river discontinuum. Freshw. Biol. 2002, 47, 641-660.

74. Pringle, C.M.; Naiman, R.J.; Bretschkco, G.; Karr, J.R.; Oswqood, M.W.; Webster, J.R.; Welcomme, R.L.; Winterbourn, M.J. Patch dynamics in lotic systems: The stream as a mosaic. J. N. Am. Benthol. Soc. 1988, 7, 503-524. 
75. Pringle, C.M. What is hydrological connectivity and why is it ecologically important? Hydrol. Process. 2003, 17, 2685-2689.

76. Willson, M.F.; Gende, S.M.; Marston, B.H. Fishes and the forest: Expanding perspectives on fish-wildlife interactions. Bioscience 1998, 48, 455-462.

77. Holtgrieve, G.W.; Schindler, D.E.; Jewett, P.K. Large predators and biogeochemical hotspots: Brown bear (Ursus arctos) predation on salmon alters nitrogen cycling in riparian soils. Ecol. Res. 2009, 24, 1125-1135.

78. Wipfli, M.S.; Baxter, C.V. Linking ecosystem food webs, and fish production: Subsidies in salmonids watersheds. Fisheries 2010, 35, 373-387.

79. Dale, V.H.; Pearson, S.M.; Offerman, H.L.; O’Neill, R.V. Relating patterns of land-use change to faunal biodiversity in the central Amazon. Conserv. Biol. 1994, 8, 1027-1036.

80. Hemstad, N.A.; Newman, R.M. Local and landscape effects of past forest harvest on stream habitat and fish assemblage. Am. Fish. Soc. Symp. 2006, 48, 413-427.

81. Welsh, H.H., Jr.; Hodgson, G.R.; Duda, J.J.; Emlen, J.M. Faunal assemblages and multi-scale habitat patterns in headwater tributaries of the South Fork Trinity River-An unregulated river embedded within a multiple-use landscape. Anim. Biodivers. Conserv. 2010, 33, 63-87.

82. Pollett, K.L.; Maccracken, J.G.; Macmahon, J.A. Stream buffers ameliorate the effects of timber harvest on amphibians in the Cascade Range of Southern Washington, USA. For. Ecol. Manag. 2010, 260, 1083-1087.

83. Kroll, A.J. Sources of uncertainty in stream-associated amphibian ecology and responses to forest management in the Pacific Northwest, USA: A review. For. Ecol. Manag. 2009, 257, 1188-1199.

84. Kroll, A.J.; Risenhoover, K.; McBride, T.; Beach, E.; Kernohan, B.J.; Light, J.; Bach, J. Factors influencing stream occupancy and detection probability parameters of stream-associated amphibians in commercial forests of Oregon and Washington, USA. For. Ecol. Manag. 2008, 255, 3726-3735.

85. Kroll, A.J.; MacCracken, J.G.; McBride, T.C.; Bakke, J.; Light, J.; Peterson, P.; Bach, J. Basin-scale surveys of stream-associated amphibians in intensively managed forests. J. Wildl. Manag. 2010, 74, 1580-1587.

86. Pauly, D. Anecdotes and the shifting baseline syndrome in fisheries. TREE 1995, 10, 430.

87. MacCracken, J.G.; Stebbings, J.L.; Tyson, J.A.; Hayes, M.P. Effects of forest canopy gaps on stream-associated amphibians: Preliminary results. Wash. Dept. Nat. Res., Olympia, WA. 2009.

88. Diller, L.V.; Wallace, R.L. Distribution and habitat of Rhyacotriton variegatus in managed young forests in north coastal California. J. Herpetol. 1996, 30, 184-191.

89. Russell, K.R.; Mabee, T.J.; Cole, M.B.; Rochelle, M.J. Evaluating biotic and abiotic influences on torrent salamanders in managed forests of western Oregon. Wildl. Soc. Bull. 2005, 33, 1413-1424.

90. Ashton, D.T.; Marks, S.B.; Welsh, H.H., Jr. Evidence of continued effects from timber harvesting on lotic amphibians in redwood forests of northwestern California. For. Ecol. Manag. 2006, 221, 183-193.

91. Schmidt, B.R. Steps toward better amphibian conservation. Anim. Conserv. 2008, 11, 469-471. 
92. Stoddard, J.L.; Larsen, D.P.; Hawkins, C.P.; Johnson, R.K.; Norris, R.H. Setting expectations for the ecological condition of streams: The concept of reference condition. Ecol. Appl. 2006, 16, 1267-1276.

93. Mallory, M.A.; Richardson, J.S. Complex interactions of light, nutrients and consumer density in a stream periphyton-grazer (tailed frog tadpoles) system. J. Anim. Ecol. 2005, 74, 1020-1028.

94. Whiles, M.R.; Lips, K.R.; Pringle, C.M.; Kilham, S.S.; Bixby, R.J.; Brenes, R.; Connelly, S.; Colin-Gaud, J.C.; Hunte-Brown, M.; Huryn, A.D.; Montgomery, C.; Peterson, S. The effects of amphibian populations declines on the structure and function of neotropical stream ecosystems. Front. Ecol. Environ. 2006, 4, 27-34.

95. Reid, L.M. Understanding and evaluating cumulative watershed impacts. General Technical Report RMRS-GTR-231. In Cumulative Watershed Effects of Fuel Management in the Western United States; Elliot, W.J., Miller, I.S., Audin, L.J., Eds.; US Forest Service Rocky Mountain Research Station: Fort Collins, CO, USA, 2010; pp. 277-298.

96. Williams, J.E.; Williams, R.N.; Thurow, R.F.; Elwell, L.; Philipp, D.P.; Harris, F.A.; Kershner, J.L.; Martinez, P.J.; Miller, D.; Reeves, G.H.; Frissell, C.A.; Sedell, J.R. Native fish conservation areas: A vision for large-scale conservation of native fish communities. Fisheries 2011, 36, 267-277.

97. Yamada, H.; Nakamura, F. Effects of fine sediment accumulation on the redd environment and the survival rate of masu salmon (Oncorhynchus masou) embryos. Landsc. Ecol. Eng. 2009, 5, 169-181.

98. Thrush, S.F.; Hewitt, J.E.; Cummings, V.J.; Ellis, J.I.; Hatton, C.; Lohrer, A.; Norkko, A. Muddy waters: Elevating sediment input to coastal and estuarine habitats. Front. Ecol. Environ. 2004, 2, 299-306.

99. Sommerfield, C.K.; Wheatcroft, R.A. Late Holocene sediment accumulation on the northern California shelf: Oceanic, fluvial, and anthropogenic influences. Geol. Soc. Am. Bull. 2007, 119, 1120-1134.

100. Litschert, S.E.; MacDonald, L.H. Frequency and characteristics of sediment delivery pathways from forest harvest units to streams. For. Ecol. Manag. 2009, 259, 143-150.

101. California Department of Forestry and Fire Protection. California Forest Practice Rules. Title 14, California Code of Regulations. Chapters 4, 4.5, and 10; The California Department of Forestry and Fire Protection Resource Management, Forest Practice Program: Sacramento, CA, USA, 2011.

102. Department of Agriculture, Rules and Regulations. Federal Register, Volume 76, No. 30, 14 February 2011.

103. Wallington, T.J.; Hobbs, R.J.; Moore, S.A. Implications of current ecological thinking for biodiversity conservation: A review of the salient issues. Ecol. Soc. 2005, 10, 15:1-15:16.

104. Keith, H.; Mackey, B.G.; Lindenmayer, D.B. Re-evaluation of forest biomass carbon stocks and lessons from the world's most carbon-dense forests. Proc. Natl. Acad. Sci. USA 2009, 106, 11635-11640.

105. Mackey, B.G.; Keith, H.; Berry, S.L.; Lindenmayer, D.B. Green Carbon: The Role of Natural Forests in Carbon Storage; ANU E-Press: Canberra, Australia, 2008. 
106. Intergovernmental Panel on Climate Change. Climate Change 2007: The Physical Basis; Cambridge University Press: Cambridge, UK, 2007.

107. Chapin, F.S.; Carpenter, S.R.; Kofinas, G.P.; Folke, C.; Abel, N.; Clarke, W.C.; Olsson, P.; Stafford Smith, D.M.; Walker, B.; Young, O.R.; et al. Ecosystem stewardship: Sustainability strategies for a rapidly changing planet. TREE 2009, 25, 241-249.

(C) 2011 by the author; licensee MDPI, Basel, Switzerland. This article is an open access article distributed under the terms and conditions of the Creative Commons Attribution license (http://creativecommons.org/licenses/by/3.0/). 